\title{
ARCHAEAN TONALJTIC-TRONDHJEMITIC AND GRANITIC PLUTONISM IN THE GAVIÃO BLOCK, SAG FRANCISCO CRATON, BAHIA, BRAZIL: GEOCHEMICAL AND GEOCHRONOLOGICAL CHARACTERISTICS
}

\author{
LUIZ ROGÉRIO BASTOS LEAL*, WILSON TEIXEIRA**,JOSÉ CARLOS CUNHA**** \& \\ MOACIR JOSÉ BUENANO MACAMBIRA***
}

\begin{abstract}
RESUMO PLUTONISMO TONALÍTICO-TRONDHJEMÍTICO E GRANÍTICO ARQUEANO NO BLOCO DO GAVIÃO CRATON DO SÃO FRANCISCO, BAHIA, BRASIL: ENSAIO GEOQUÍMICO E GEOCRONOLÓGICO Os terrenes granito-gnaissicos do Bloco do Gavião (BG) objeto do presente trabalho, representam a maior exposição do embasamento arqueano do Craton do São Francisco, sendo portanto, uma area-chave para o entendimento da evolução da crosta primitiva da plataforma Sul-Americana. As rochas granfticas e gndissicas estao intimamente associadas com os greenstone belts de Umburanas e Contendas Mirante. O grau metamorfico destes terrenes varia de xisto verde a anfibolito. De outra parte, estas rochas foram intensamente deformadas e intrudidas por granites durante o Arqueano e Paleoproterozoico. A evolução primitiva do Bloco do Gavião é marcada pela formação de niicleos granitoides, a partir de vários episódios de plutonismo TTG com idades variando entre 3,2 e 3,4 Ga. As idades modelo Sm-Nd nestes granitbides variam entre 3,2 e 3,6 Ga, indicando o envolvimento de crosta sidlica na gênese destas rochas, conforme corroborado pelos $\varepsilon_{\mathrm{Nd}}(\mathrm{t})$ negatives entre -4.0 e -1.3 . Entre 3,1 e 2,5 Ga, atividades vulcanicas e sedimentares atingiram o Bloco do Gavião com a formafao dos greenstone belts de Umburanas e Contendas Mirante. Finalmente, a evolução arqueana é representada por intrusão de granitdides ha cerca de 2,8 e 2,5 Ga. Durante o Paleoproterozóico, o Bloco Gavião foi deformado e metamorfisado regionalmente e intrudido por granites com idades entre 2,1 e 1,9 Ga. Durante o Meso e Neoproterozoico, atividades tectono-metamdrficas estiveram presentes neste segmento de crosta arqueana promovendo a intruSão de diques maficos e o rejuvenescimento isotopico das idades $\mathrm{K}-\mathrm{Ar}$ e $\mathrm{Rb}-\mathrm{Sr}$.
\end{abstract}

Palavras-chave: Geoquimica, geocronologia, Arqueano

\begin{abstract}
The granitic-gneissic terranes of the Gavião Block in the central-southern São Francisco Craton are a key area to the understanding of the Archaean evolution of the South American Platform. The Archaean granitic-gneissic rocks are intimately associated with the Umburanas and Contendas Mirante greenstone belts. The metamorphic grades vary from greenschist to amphibolite facies. These rocks were intensely deformed and intruded by Paleoproterozoic granites. The main evolution of the Gavião Block is marked by the formation of granitoid nuclei during various episodes of TTG plutonism between 3.2 and 3.4 Ga. The $\mathrm{T}_{\mathrm{DM}} \mathrm{Sm}-\mathrm{Nd}$ model ages for these granitoids range from 3.2 and $3.6 \mathrm{Ga}$, indicating involvement of sialic crust in their genesis, in agreement with the $\varepsilon_{\mathrm{Nd}}(\mathrm{t})$ values between -4.0 and -1.3 . Between 3.1 and $2.5 \mathrm{Ga}$, the Gavião Block was affected by volcanic and sedimentary activity associated with the formation of the Umburanas and Contendas Mirante greenstone belts, intruded by granites about 2.75 and 2.5 Ga ago.

During the Paleoproterozoic, the Gavião Block was regionally deformed and metamorphosed, and intruded by granites between 2.1 and $1.9 \mathrm{Ga}$. During the Mesoproterozoic, tectonic and metamorphic activity occurred between 1.2 and $1.0 \mathrm{Ga}$ as suggested by resetting of $\mathrm{Rb}-\mathrm{Sr}$ and $\mathrm{K}-\mathrm{Ar}$ systematics. Finally, regional tectono-thermal overprints in the areas occurred during the Neoproterozoic. These episodes are accompanied by the intrusion of mafic dikes at about $0.9 \mathrm{Ga}$. K-Ar ages given by biotites fall within the range $0.5-0.7 \mathrm{Ga}$ and mark the end of the cratonization stage.

Keywords: geochemistry, geochronology, Archaean
\end{abstract}

INTRODUCTION The São Francisco Craton - CSF (Fig.lA) resulted from accretions of crustal segments of Archaean age and mobile belts, whose evolutionary history took place between the PalaeoArchaean and the Paleoproterozoic (Cordani \& Brito Neves 1982, Teixeira \& Figueiredo 1991, Marinho et al. 1992, Alkimim et al. 1993). These continental accretion processes are marked by several volcano-plutonic episodes of 1.9 to $3.4 \mathrm{Ga}$ (Brito Neves et al. 1980, Cordani et al. 1985, Mascarenhas \& Garcia 1989, Sabate et al. 1990, Martin etal. 1991, Marinho 1991, Carneiro 1992, Nutman \& Cordani 1993, Noce 1995, Teixeira et al. 1996, Bastos Leal et al. 1997). Finally, in the Neoproterozoic CSF acted as the foreland for the development of mobile belts, during the Brasiliano Cycle evolution, between 0.57 and 1.0 Ga (Brito Neves et al. 1980, Alkimin et al. 1993, Fuck et al. 1993).

The Gavião Block (BG), subject of present work, is part of an Archaean granite-greenstone terrain and represents the largest exposition of the CSF Archaean basement, thus being a key area to the understanding of the evolution of the primitive crust in the South-American Platform.

Pioneer geochronological studies carried out in BG were based essentially on $\mathrm{K}-\mathrm{Ar}$ and $\mathrm{Rb}-\mathrm{Sr}$ geochronology (e.g.
Cordani \& lyer 1979, Brito Neves et al. 1980, Cordani et al. 1985, Mascarenhas \& Garcia 1989). More recently, this eratonic segment has been a target for geochronological investigations by several methodologies (K-Ar, $\mathrm{Rb}-\mathrm{Sr}, \mathrm{Pb}-\mathrm{Pb}, \mathrm{Sm}-$ Nd and U-Pb) (Marinho 1991, Martin et al. 1991, Nutman \& Cordani 1993, Bastos Leal \& Teixeira 1994, Santos-Pinto 1996, Bastos Leal et al. 1996, Cunha et al. 1996). Such a variety of geochronological methods allowed defining the main regional tectono-magmatic events and revealed the polycyclic character of the crustal evolution. They also increased significantly the understanding of the geological processes involved in the genesis and evolution of CSF during the Archaean and Palaeoproterozoic.

New geochronological (Rb-Sr, ${ }^{207} \mathrm{~Pb}-{ }^{206} \mathrm{~Pb}$ and $\mathrm{Sm}-\mathrm{Nd}$ ) determinations and geochemical analyses will be presented and discussed, concerning not only the BG gneiss-migmatitic terranes, but also the Lagoa da Macambira and Malhada de Pedras intrusive granites. The results of the latest geochronological studies referred to in the literature will also be commented aiming at integration with the presented data and leading to the understanding of the BG crustal evolution.

* Centro de Pesquisas Geocronologicas do Institute de Geociencias da Universidade de São Paulo/ Curso de pós-graduação do Institute de Geociências da Universidade de São Paulo, caixa postal 11348, CEP. 5422-970, São Paulo, SP, Brasil.

** Departamento de Geologia Geral, Institute de Geociencias da Universidade de São Paulo, caixa postal 11348, CEP. 5422-970, São Paulo, SP, Brasil.

*** Companhia Baiana de Pesquisas Minerals, 4 a avenida, 460 - Centro Administrativo da Bahia, Salvador, Bahia, Brasil. CEP. 41750-300.

***!!Laboratório de Geologia Isotópica da Universidade Federal do Pará-LGI/UFPa. 


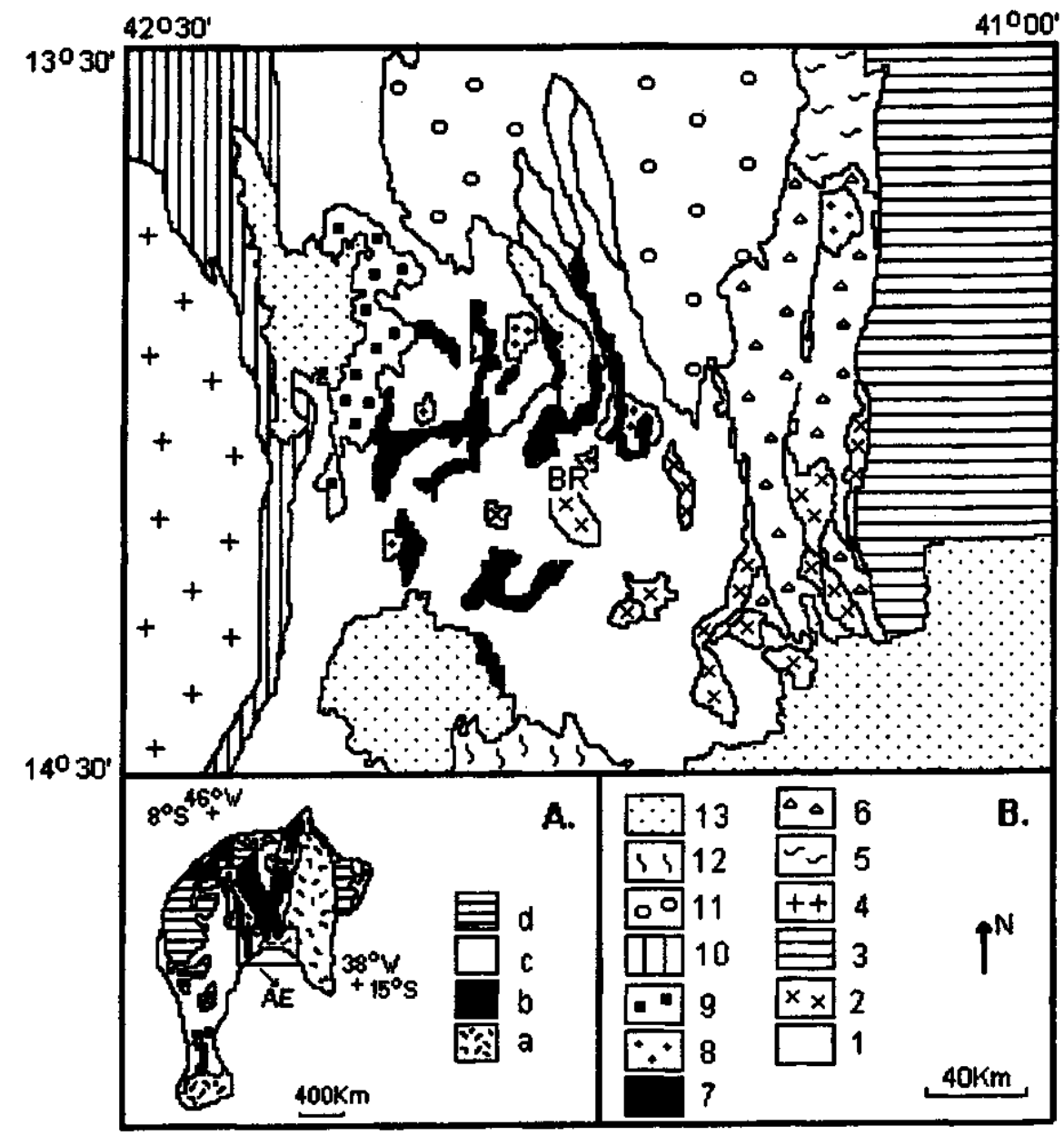

Figure 1 - Geological outline of the Gavião Block (Adapted from Barbosa \& Dominguez 1996). 1A - (a) Archaean and Paleoproterozoic granitic-greenstone andgranulite terranes, (b) Mesoproterozoic covers, (c) Neoproterozoic covers, (d) Phanerozoic covers. AE - Study area. IB - 1 = Gavião Block-Archaean gneisses, $2=$ Gavião Block-Archaean granitoids, $3=$ Jequie Block - Archaean high grade gneisses and granulites, 4 = Correntina-Guanambi Block - Archaean and Paleoproterozoic medium grade gneisses, 5 = Mairi Block - Archaean gneisses, 6 = Gavião Block-Contendas-Mirante supracrustal belt (Archaean and Paleoproterozoic), 7 = Umburanas greenstone belt (Archaean), 8 = Paleoproterozoic granites, 9 = Mesoproterozoic Lagoa Real Complex 10 = Mesoproterozoic Espinhago Supergroup $11=$ Neoproterozoic sediments $12=$ Neoproterozoic fold belts $13=$ Cenozoic sediments, $B R=$ Brumado city, $A E=$ study área.

Figura 1 - Mapa geologico simplificado do Bloco do Gavião (Adaptado de Barbosa \& Dominguez 1996) 1A - (a) Terrenos granito-greenstone e granuliticos do Arqueano e Paleoproterozóico, (b) Coberturas do Mesoproterozdico, (c) Coberturas do Neoproterozoico, (d) coberturas Fanerozóicas. AE - Area estudada. IB 1 = Bloco Gavião - Gnaisses arqueanos, 2=Granitóides arqueanos, 3 = Bloco Jequie -gnaisses de alto grau metamórfico e granulitos, $4=$ Bloco Correntina-Guanambi - gnaisses de medio grau metamorfico (Arqueano e Paleoproterozóico), $5=$ Bloco de Mairi -gnaisses arqueanos, $6=$ Greenstone belt de Contendas Mirante (Arqueano e Paleoproterozóico), 7 = Bloco Gavião -greenstone belt de Umburanas, 8 = granites paleoproterozoicos, $9=$ Complexo Lagoa Real (Mesoproterozoico) $10=$ Supergrupo Espinhafo $11=$ Sedimentos Neoproterozoicos $12=$ Cinturoes de dobramentos Neoproterozoicos $13=$ Sedimentos cenozóicos, BR $=$ Cidade de Brumado, $\mathrm{AE}=$ area estudada.

REGIONAL GEOLOGIC SETTING BG is composed of variably migmatized granitic-gneiss terranes and Archaean volcanosedimentary domains, intruded by syn- to post-tectonic Paleoproterozoic granitoids (Fig. IB). Thrust faults and tangential shear zones that evolved during the Transamazonico Cycle mark the eastern and western limits of this crustal segment (Sabate et al. 1990, Cunha \& Froes 1994, Barbosa \& Dominguez 1996). The BG northern portion is partially covered by Meso-and Neoproterozoic sedimentary rocks, respectively of the Chapada Diamantina and Bambui Groups. The southern limit is represented by the contact with the Ara5uai-Piripa Fold Belt, which evolved during the Brasiliano Cycle between 0.55 and 0.65 Ga (Fuck et al. 1993, Rocha\& Fuck 1996).
The BG primitive evolution during the PalaeoArchaean is marked by the formation of granitoid nuclei through successive episodes of TTG (Tonalites, Trondhjemites and Granodiorites) plutonism, with ages varying between 3.15 and 3.42 Ga. Such plutonism is well exemplified by the Sete Voltas, Boa Vista/Mata Verde, Bernarda, Aracatu and Lagoa da Macambiramassifs (Martin etal. 1991,Nutman\&Cordani 1993, Santos-Pintoe/a/. 1995,BastosLealefa/. 1996). On the other hand, Sm-Nd model ages $\left(\mathrm{T}_{\mathrm{DM}}\right)$ between 3.2 to $3.7 \mathrm{Ga}$ referred in the literature indicate a still not well identified recycling of primitive continental crust during the genesis of these TTG terranes (Marinho et al. 1992, Santos-Pinto 1996, Satoetal. 1996, Cunha et al. 1996). 
During the MesoArchaean BG was the target of granodioritic and granitic plutonism, represented by the Lagoa do Morro, Serra dos Pombos and Malhada de Pedras massifs. The plutonism evolution seems to be synchronous with the intrusion of enderbitic-charnockitic calc-alkaline rocks in the Jequie Block, whose ages vary from 2.8 to $2.9 \mathrm{Ga}$. The formation of these calc-alkaline rocks in the Jequie Block has been linked with a geodynamic mechanism of oceanic crust subduction to the west underneath BG (Barbosa et al. 1992).

The available $\mathrm{Rb}-\mathrm{Sr}$ geochronological data set for the $\mathrm{BG}$ gneisses show that the ages cluster around $2.7 \mathrm{Ga}$. These have been linked to the role played by tectonic-metamorphic phenomena associated with the Jequie Cycle (Brito Neves et al. 1980, Cordani et al. 1985, Mascarenhas \& Garcia 1989). Such interpretation is supported by another $\mathrm{Rb}-\mathrm{Sr}$ geochronological data set obtained for rocks from the Jequie Block with ages around $2.7 \mathrm{Ga}$ which represent the peak of granulite metamorphism in this crustal segment (Barbosa 1990, Barbosa et al. 1992). $\mathrm{Rb}$-Sr ages around $2.7 \mathrm{Ga}$ are also found in the Guanambi-Correntina Block, west of BG. On the other hand, the $\mathrm{Rb}-\mathrm{Sr}$ isotopic pattern obtained for BG migmatites mainly shows ages between 1.8-1.9 Ga, suggesting that isotopic rejuvenation phenomena took place during the Transamazonico Cycle. Barbosa \& Dominguez (1996) have recently recognized a tectono-metamorphic overprint in the Jequie Block region that took place in the Paleoproterozoic. Its climax must have occurred ca. 2.1-2.0 Ga ago.

The Contendas-Mirante, Umburanas and Ibitira-Brumado volcanosedimentary sequences present lithostratigraphic and tectono-metamorphic arrangements typical of Archaean greenstone belts (Marinho 1991, Schrank \& Silva 1993, Cunha \& Froes 1994). The geochronologic record of these supracrustals points to the opening of an ocean 3.0-3.3 Ga ago, with the spreading of komatiites and basalts. The felsic calcalkaline volcanism of the intermediate units of the Umburanas and Contendas-Mirante greenstones occurred $c a .2 .75$ and
2.50 Ga ago respectively (Marinho 1991, Cunha et al. 1996, Bastos Leal et al. 1997).

The Paleoproterozoic granites in BG are represented by bodies of different compositions and natures (Sabate et al. 1990, Froes et al. 1994, Bastos Leal \& Teixeira 1994), intrusive in both the Archaean volcanosedimentary units and $\mathrm{Ar}$ chaean gneiss-migmatite terranes (Fig. IB). They are coarseto fine-grained, commonly porphyritic, have an incipient foliation and a tonalitic to alkali granite composition. Sometimes these plutons are lineated and/or foliated especially where regional shear corridors crosscut them. Available $\mathrm{Sr}$ and $\mathrm{Nd}$ isotopic data show ases ranging between 1.8 and 2.0 Ga, with initial ratios $\left.{ }^{87} \mathrm{Sr}{ }^{86} \mathrm{Sr}\right)=0,711-0,760$ and $\mathrm{Nd}_{\mathrm{t}}=$ $-6,9$ to $-15,6$. Such data, together with Sm-Nd model ages $\left[\left(\mathrm{T}_{\mathrm{DM}}\right)=2.6-3.4 \mathrm{Ga}\right]$, suggest that these granites are the product of primitive continental crust recycling during the evolution of the Transamazônico Cycle (Bastos Leal \& Teixeira 1994, Santos-Pinto et al. 1995, Cunha et al. 1996).

The apparent K-Ar ages reported for amphiboles from rocks of the BG infrastructure range between 1.8 and $1.0 \mathrm{Ga}$, revealing the complexity of the Proterozoic thermal evolution. On the other hand, K-Ar micas ages vary from 0.75 to 0.45 $\mathrm{Ga}$, reflecting a strong regional reheating related to the Brasiliano Cycle, especially along the Paramirim Valley (Mascarenhas \& Garcia 1989, Teixeira \& Canzian 1994).

ANALYTICAL METHODS Eighteen complete chemical analyses including REE were carried out at ACTLAB - Activation Laboratories (Ontario, Canada), twelve corresponding to samples from TTG terranes (Table 1) and six from the intrusive granitoids (Table 2). The major $\left(\mathrm{SiO}_{2}, \mathrm{Al}_{2} \mathrm{O}_{3}, \mathrm{MgO}\right.$, $\left.\mathrm{CaO}, \mathrm{Na}_{2} \mathrm{O}, \mathrm{K}_{2} \mathrm{O}\right)$ and minor $\left(\mathrm{MnO}\right.$ and $\left.\mathrm{P}_{2} \mathrm{O}_{5}\right)$ elements were analyzed by Inductively Coupled Plasma - ICP. Trace (Rb, $\mathrm{Sr}, \mathrm{Ba}, \mathrm{Zr}, \mathrm{Ce}, \mathrm{V}, \mathrm{Pb}, \mathrm{Cu}, \mathrm{Ni}, \mathrm{Zn}, \mathrm{Ta}, \mathrm{Th}, \mathrm{U}, \mathrm{Hf}$ and $\mathrm{Y}$ ) elements were analyzed by Inductively Coupled Plasma Mass Spectrometry -ICP-MS and rare earth $(\mathrm{Ce}, \mathrm{Nd}, \mathrm{Tb}, \mathrm{La}, \mathrm{Eu}$, $\mathrm{Yb}, \mathrm{Sm}$ and $\mathrm{Lu}$ ) elements by neutron activation. The estimated

Table 1 - Major, trace and rare-earth element of Archaean gneiss-migmatitic rocks of the Gavião Block (GB). mg\# - 100.mol. $\mathrm{MgO} /(\mathrm{MgO}+\mathrm{FeO})$.

Tabela 1 - Analises quimicas de elementos maiores, traços e terras raras para as rochas gnássicas-migmátiticas arqueanas do Bloco do Gavião (BG). mg\# = 1OO.mol. $\mathrm{MgO} /(\mathrm{MgO}+\mathrm{FeO})$.

\begin{tabular}{|c|c|c|c|c|c|c|c|c|c|c|c|c|c|c|}
\hline SAMPLE & $\begin{array}{c}\text { BR-JC- } \\
\text { 14D }\end{array}$ & $\begin{array}{c}\text { BR-JC- } \\
\text { l4E }\end{array}$ & $\begin{array}{c}\text { BR-JC: } \\
14 \mathrm{C}\end{array}$ & $\begin{array}{c}\mathrm{B} \overline{\mathrm{R}}-\mathrm{JC}- \\
178 \mathrm{~A}\end{array}$ & $\begin{array}{c}\mathrm{BR}-\mathrm{JC}- \\
178 \mathrm{~B}\end{array}$ & $\begin{array}{c}\text { BR-JC- } \\
02\end{array}$ & $\begin{array}{c}\text { BR-JC- } \\
124\end{array}$ & $\begin{array}{c}\text { BR-JC- } \\
188\end{array}$ & $\begin{array}{c}\text { BR-JC- } \\
45 \mathrm{C}\end{array}$ & $\begin{array}{c}\text { BR-JC- } \\
45 \mathrm{~A}\end{array}$ & $\begin{array}{c}\text { BR-JC- } \\
290 \mathrm{~A}\end{array}$ & $\begin{array}{c}\text { BR-JC- } \\
290 \mathrm{~J}\end{array}$ & $\begin{array}{l}\text { Martin } \\
(1994)\end{array}$ & \begin{tabular}{|l} 
Condie \\
$(1993)$
\end{tabular} \\
\hline $\mathrm{N}^{\text {"I }}$ ANALYSE & 1 & 2 & 3 & 4 & 5 & 6 & 7 & 8 & 9 & 10 & 11 & 12 & TTG & GFANITES \\
\hline $\mathrm{SiO}_{2}$ & 76.79 & 72.88 & 74.31 & 73.08 & 68.21 & 68.91 & 72.11 & 71.98 & 73.19 & 78.61 & 75.86 & 75,60 & 69.79 & 72.40 \\
\hline $\mathrm{TiO}_{2}$ & 0.21 & 0.16 & 0.23 & 0.22 & 0.44 & 0.18 & 0.21 & 0.33 & 0.12 & 0.18 & 0.18 & 0.23 & 0.34 & 0.25 \\
\hline $\mathrm{A} 12 \mathrm{O}_{3}$ & 113.02 & 15.06 & 14.22 & 14.95 & 16.87 & 16.79 & 15.24 & 15.44 & 14.98 & 10.80 & 13.3 .1 & $\$ 3.30$ & 15.56 & 14.80 \\
\hline $\mathrm{Fe}_{2} \mathrm{O}_{3}$ & 1.54 & 1.12 & 1.58 & 1.76 & 3,47 & 1.69 & 1.66 & 2,41 & 0.96 & 2.83 & 1.30 & 1.79 & 3.12 & 1.94 \\
\hline MnO & 0.03 & 0.02 & 0.04 & 0.03 & 0,06 & 0.03 & 0.03 & 0.04 & 0.02 & 0.04 & 0.03 & 0.30 & 0.05 & - \\
\hline $\mathrm{MgO}$ & 0.64 & 0.41 & 0.61 & 0.55 & 1.23 & 0.60 & 0.62 & 0.77 & 0.27 & 0.06 & 0.24 & 0.54 & 1.18 & 0.37 \\
\hline $\mathrm{CaO}$ & 1.89 & 1.30 & 1.82 & 2.05 & 2.90 & 1.41 & 2.72 & 2.73 & 1.31 & 0.65 & 1.10 & 1.37 & 3.19 & 1.18 \\
\hline $\mathrm{Na}_{2} \mathrm{O}$ & 4.62 & 1.56 & 4.61 & 4.91 & 5.34 & 4.67 & 4.78 & 5.28 & 5.04 & 3.07 & 3.61 & 3.45 & 4.88 & 3.16 \\
\hline $\mathrm{K}_{2} \mathrm{O}$ & 1.43 & 4.30 & 1.92 & 2.46 & 1.39 & 5.51 & 2.29 & 1.46 & 4.15 & 3.22 & 4,83 & 3.60 & 1.76 & 4.94 \\
\hline $\mathrm{P}_{2} \mathrm{O}_{3}$ & 0.08 & 0.06 & 0.08 & 0.07 & 0.13 & 0.07 & 0.07 & 0.09 & 0.09 & 0.03 & 0.03 & 0.05 & 0.13 & 0.08 \\
\hline TOTAL & 100.25 & 99.87 & 99.42 & 100.08 & 100.04 & 99.86 & 99.73 & 100.53 & 100.13 & 99.49 & 100.49 & 100.23 & • & • \\
\hline mg\# & 0.29 & 0.42 & 0.43 & 0.38 & 0,41 & 0.41 & 0.43 & 0.39 & 0.36 & 0.40 & 0.27 & 0.37 & 0.43 & \\
\hline $\mathbf{R b}$ & 140 & 119 & 79 & 60 & 86 & 138 & 65 & 75 & 73 & 77 & 175 & 173 & 55 & 150 \\
\hline Cs & 1.80 & 1.50 & 1.90 & 0.90 & 2.10 & 1.20 & 0.70 & 1.10 & 1.00 & 0.60 & 1.70 & 1.40 & - & • \\
\hline $\mathbf{B a}$ & 536 & 492 & 217 & 353 & 120 & 696 & 419 & 310 & 648 & 538 & 513 & 516 & 690 & 765 \\
\hline Sr & 118 & 244 & 262 & 406 & 463 & 239 & 509 & 319 & 133 & 80 & 110 & 136 & 454 & 145 \\
\hline $\mathbf{T a}$ & 3.00 & $<0.50$ & 4.50 & 0.60 & $<0.50$ & 0.90 & $<0.50$ & 0.60 & 5.50 & 5.30 & $<0.50$ & 1.20 & 0.71 & 1,0 \\
\hline tif & 4.50 & 3.10 & 3.50 & 3.20 & 4.60 & 3.90 & 2.60 & 4.30 & 7.90 & 12.60 & 3.90 & 4.20 & 4.5 & 4.5 \\
\hline $\mathrm{Z}_{\mathrm{J}}$ & 180 & 91 & 121 & 129 & 201 & 172 & 86 & 197 & 290 & 401 & 126 & 145 & 152 & 155 \\
\hline $\mathbf{Y}$ & 5 & 4 & 9 & 11 & 6 & 16 & 4 & 5 & 90 & 26 & 13 & 20 & 7.5 & 20 \\
\hline Th & 58.90 & 13.00 & 14.60 & 4.30 & 3.80 & 10.80 & 1.50 & 9.10 & 163.00 & 31.60 & 15.00 & 18.00 & 6.9 & 15 \\
\hline t & 4.60 & 1.70 & 3.30 & 0.20 & $<0.10$ & 0.80 & -0.10 & 1.50 & 3.40 & 1.80 & 2.70 & 4.40 & 1.6 & 3.5 \\
\hline $\mathbf{L a}$ & 55.00 & 18.40 & 23.8 & 30.50 & 22.40 & 33.40 & 14.60 & 43.00 & 260.00 & 70.20 & 44.90 & 50.50 & 32 & 50 \\
\hline $\mathrm{Ce}$ & 46.00 & 37.00 & 47.00 & 55.00 & 40.00 & 66.00 & 28.00 & 71.00 & 551.00 & 142.00 & 88.00 & 96.00 & 56 & 95 \\
\hline Nd & 18.00 & 16.00 & 18.00 & 19.00 & 16.00 & 24.00 & 10.00 & 24.00 & 237.00 & 66.00 & 30.00 & 32.00 & 21.4 & 46 \\
\hline $\mathrm{Sn}$ & 3.10 & 2,31 & 2.88 & 2.39 & 2.87 & 3.54 & 1.40 & 3.06 & 45,60 & 12.40 & 4.70 & 5.18 & 3.3 & 6.3 \\
\hline $\mathbf{E u}$ & 0.56 & 0.54 & 0.64 & 0.68 & 0.67 & 0.77 & 0.54 & 0.76 & 3.22 & 2.21 & 0.64 & 0.59 & 0.92 & 0.85 \\
\hline $\mathbf{T b}$ & $<0.50$ & $<0.50$ & $\varangle 0.50$ & $<0.50$ & $<0,50$ & $<0,50$ & $<0.50$ & $<0.50$ & 4.60 & 1.50 & 0.60 & 1.00 & 2.2 & 0.65 \\
\hline $\mathbf{Y b}$ & 0.47 & 0.30 & 0.68 & 0.61 & 0.44 & 1.14 & 0.25 & 0.31 & 5.30 & 2.04 & 0.89 & 1.64 & 0.59 & 2.0 \\
\hline Lu & 0.07 & 0.04 & 0.08 & 0.10 & 0.07 & 0.15 & 0.04 & 0.04 & 0.72 & 0.26 & 0.16 & 0.23 & 0.55 & 0.32 \\
\hline
\end{tabular}


errors for major and trace elements vary between 2 and $5 \%$. In order to establish geochemical comparisons, samples from BG gneiss terranes affected by either incipient (analyses $n$. 1 to 5) or strong migmatization processes (analyses n. 6 to 8 ) were analyzed.

Table 2 - Major, trace and rare-earth element of Archaean granitoid rocks (Lagoa Macambira and Malhada Pedras). $m g \#=100 . \mathrm{mol} . \mathrm{MgO} /(\mathrm{MgO}+\mathrm{FeO})$.

Tabela 2 - Analises químicas de elementos maiores e tra9os para as rochas granitdides arqueanas (Malhada de Pedras e Lagoa da Macambira) do BG. $\mathrm{mg} \#=10 \mathrm{O} \cdot \mathrm{mol} . \mathrm{MgO} /(\mathrm{MgO}+\mathrm{FeO})$.

\begin{tabular}{|c|c|c|c|c|c|c|}
\hline N SAMPEE & $\begin{array}{c}\text { BR-JC- } \\
10 \mathrm{~A} \\
\end{array}$ & $\begin{array}{c}\text { BR-JC- } \\
11 \mathrm{H}\end{array}$ & $\begin{array}{c}\text { BR-JC- } \\
111\end{array}$ & $\begin{array}{c}\text { BR-JC- } \\
16 \mathrm{~A} \\
\end{array}$ & $\begin{array}{c}\text { BR-JC. } \\
16 \mathrm{C}\end{array}$ & $\begin{array}{c}\text { BR-JC. } \\
16 \mathrm{D}\end{array}$ \\
\hline $\mathbf{N}^{2}$ ANALYSE & 1 & 2 & 3 & 4 & 5 & 6 \\
\hline $\mathrm{SiO}_{2}$ & 71.89 & 75,38 & 75.35 & 73.84 & 73.31 & 73.02 \\
\hline $\mathrm{THO}_{2}$ & 0.27 & 0.21 & 0.14 & 0.26 & 0.26 & 0.26 \\
\hline $\mathrm{Al}_{2} \mathrm{O}_{3}$ & 15.22 & 14.43 & 13.57 & 14.79 & 14.93 & 14.98 \\
\hline $\mathrm{Fe}_{2} \mathrm{O}_{3}$ & 2.28 & 1.99 & $1.4 \mathrm{I}$ & 1.95 & 2.05 & 1.83 \\
\hline MnO & 0.04 & 0.03 & 0.03 & 0.06 & 0.04 & 0.09 \\
\hline MgO & 0.51 & 0.36 & 0.24 & 0.54 & 0.58 & 0.40 \\
\hline $\mathrm{CaO}$ & 2.08 & 1.56 & 1.03 & 2.24 & 2.29 & 1.85 \\
\hline $\mathrm{Na}_{2} \mathrm{O}$ & 5.16 & 4.36 & 3.84 & 5.53 & 5.06 & 4.66 \\
\hline $\mathrm{K}_{2} \mathrm{O}$ & 2.64 & 3.69 & 4.66 & 10.21 & 1.95 & 3.23 \\
\hline $\mathbf{P}_{2} \mathbf{O}_{5}$ & 0.10 & 0.07 & 0.05 & 0.08 & 0.10 & 0.09 \\
\hline TOTAL & 100.19 & 100.28 & 100.32 & 100.50 & 100.57 & 100.35 \\
\hline mg\#\# & 0.31 & 0.26 & 0.25 & 0.35 & 0.36 & 0.30 \\
\hline $\mathbf{N i}$ & 3 & 2 & 4 & 4 & 5 & 4 \\
\hline $\mathbf{R b}$ & 100 & 98 & 115 & 75 & 105 & 103 \\
\hline $\mathrm{Cs}$ & 1.10 & 0.80 & 0.80 & 2.80 & 2.30 & 2.00 \\
\hline $\mathbf{B a}$ & 239 & 625 & 611 & $\$ 27$ & 274 & 456 \\
\hline $\mathbf{S r}$ & 232 & 276 & 214 & 248 & 293 & 368 \\
\hline $\mathbf{T a}$ & 0.90 & $<0.50$ & 0.80 & 4.60 & 3.70 & 4.10 \\
\hline Hf & 5.000 & 5.40 & 3.90 & 4.40 & 4.30 & 4.40 \\
\hline $\mathbf{Z r}$ & 188 & 194 & 134 & 160 & 180 & 158 \\
\hline $\mathbf{Y}$ & 7 & 9 & 7 & 11 & 6 & 7 \\
\hline Th & 9.70 & 9.50 & 13.10 & 8.40 & 9.70 & 8.00 \\
\hline $\mathrm{U}$ & 0.50 & $<0.10$ & $<0.10$ & 1.30 & 1.20 & 1.00 \\
\hline $\mathrm{L}_{\mathrm{a}}$ & 44.4 & 88.30 & 53.10 & 42.60 & 33.70 & 39.60 \\
\hline $\mathrm{Ce}$ & 82,00 & 136,00 & 88.00 & 63,00 & 59,00 & 77.00 \\
\hline Nd & 28.00 & 49.00 & 29.00 & 21.00 & 19.00 & 23,00 \\
\hline $\mathrm{Sm}$ & 3.91 & 5.28 & 3.92 & 3,30 & 2.68 & 3.25 \\
\hline Eu & 0.69 & 1.00 & 0.78 & 0.64 & 0.68 & 0.81 \\
\hline Tb & 50.50 & $\leq 0.50$ & $<0.50$ & $<0.50$ & $<0.50$ & $<0.50$ \\
\hline $\bar{Y} \mathbf{b}$ & 0.46 & 0.49 & 0.57 & 0.60 & 0.50 & 0.50 \\
\hline Lu & 0,08 & 0.10 & 0.10 & 0.09 & 0.06 & 0.05 \\
\hline
\end{tabular}

$\mathrm{Sm}-\mathrm{Nd}$ and $\mathrm{Rb}-\mathrm{Sr}$ isotopic analyses (Tables 3 and 4 respectively) were carried out at the Geochronologic Research Center of São Paulo University (CPGeO-USP), whereas ${ }^{207} \mathrm{~Pb}-$

${ }^{206} \mathrm{~Pb}$ analyses in zircons (Table 4), were carried out at the Isotopic Geology Laboratory of the Federal University of Para, Brazil (LGI-UFPa).

$\mathrm{Rb}$ and $\mathrm{Sr}$ contents were determined by X-ray fluorescence, whereas $\mathrm{Sm}$ and $\mathrm{Nd}$ values were determined by isotopic dilution. The spectrometric readings were done with CPGeO's VG-354 mass spectrometer. For the radiometric calculations the constants proposed by Steiger \& Jäger(1977) were adopted. To obtain the isochronic diagrams the linear regression method presented by Williamson (1968) was used. ${ }^{143} \mathrm{Nd} /{ }^{144} \mathrm{Nd}$ yalues wgre normalizedusing ${ }^{146} \mathrm{Nd} /{ }^{144} \mathrm{Nd}=$

0,7219 and the calculations were done with the constants proposed by Michard et al. (1985). Sm-Nd model ages $\left(\mathrm{T}_{\mathrm{DM}}\right)$ were calculated using the depleted mantle model proposed by DePaolo\{1988).

${ }^{207} \mathrm{~Pb} /{ }^{206} \mathrm{~Pb}$ analyses by evaporation of zircon monocrystals at LGI-UFPa (Table 5) followed the procedures proposed by Kober (1986), with modifications introduced by Gaudette et al. (1993). The decay constants and the isotopic ratios used in the age calculations are those listed by Steiger \& Jager (1977).

GRANITIC-GNEISS TERRANES OF THE GAVIÃO BLOCK Gneiss-Migmatitic Rocks The gneiss-migmatite terranes are composed of gneissic plutons of affinity similar to the TTG suites (see next section), with variable migmatization grades, formed by tonalites, trondhjemites, granodiorites and granites. They vary from gray to light pink and underwent metamorphism of medium amphibolite facies, locally granulite facies. Retro-metamorphism to the greenschist facies is also registered in the regions where expressive regional shear zones developed. The igneous-plutonic characteristic is mainly evidenced by the presence of preserved however generally deformed and recrystallized -feldspar megacrysts, as well as by igneous textures. Subordinately, migmatized paragneisses also occur in these terranes, but they were not investigated.

The lithologies free from migmatization present compositions which vary from tonalitic-trondhjemitic to granodioritic

Table 3 - Sm-Nd analytical data of gneiss-migmatitic and granitoids. Isotopic ratios were measured with $2 \sigma$ errors and the $\varepsilon_{N d}(t)$ values were calculated for the crystallization age using DePaolo's (1988) model.

Tabela 3 - Dados isotopicos Sm-Nd para as rochas gnaissicas-migmatticas e granitoides arqueanas do Bloco do Gavião. As razoes isotopicas foram medidas com erros de $2 \sigma$ e os valores do $\varepsilon_{\mathrm{Nd}}(\mathrm{t})$ calculation para a época de cristalização da rocha, usando o modelo de DePaolo (1988).

\begin{tabular}{|c|c|c|c|c|c|c|}
\hline SAMPLE & Sm (ppm) & Nd (ppm) & ${ }^{147} \mathrm{Sm} /{ }^{14} \mathrm{Nd}$ & ${ }^{\mathrm{T} 3} \mathrm{Nd} /{ }^{14} \mathrm{Nd}$ & $\mathrm{T}_{\mathrm{DM}}(\mathrm{Ma})$ & ENd (t) \\
\hline BR-JC-02 & $3.865 \pm 0.002$ & $24.255 \pm 0.011$ & $0.096954 \pm 0.000073$ & $0.510441 \pm 0.000030$ & $3455 \pm 46$ & -1.3 \\
\hline BR-JC-178 & $3.698 \pm 0.001$ & $19.939 \pm 0.013$ & $0.112835 \pm 0.000083$ & $0.510702 \pm 0.000030$ & $3615 \pm 55$ & -4.0 \\
\hline BR-JC-300 & $2.851 \pm 0.001$ & $18.287 \pm 0.010$ & $0.094847 \pm 0.000057$ & $0.510540 \pm 0.000030$ & $3255 \pm 45$ & 0.2 \\
\hline $\begin{array}{c}\text { BR-JC- } \\
\text { I6D }\end{array}$ & $3.419 \pm 0.002$ & $24.782 \pm 0.013$ & $0.083936 \pm 0.000061$ & $0.510239 \pm 0.000061$ & $3340 \pm 38$ & -1.8 \\
\hline $\begin{array}{c}\text { BR-JC- } \\
\text { I1H }\end{array}$ & $4.802 \pm 0.002$ & $38.737 \pm 0.030$ & $0.075428 \pm 0.000066$ & $0.510115 \pm 0.000024$ & $3269 \pm 30$ & -6.2 \\
\hline
\end{tabular}

Table 4 - Rb-Sr analytical data of the Malhada Pedras granite.

Tabela 4 - Dados analiticos Rb-Sr do granitoide de Malhada de Pedras.

\begin{tabular}{|c|c|c|c|c|c|}
\hline $\mathbf{N}^{\mathbf{Q}} \mathbf{L A B}$ & SAMPLE & $\mathbf{R b}(\mathbf{p p m})$ & Sr (ppm) & ${ }^{87} \mathbf{R b} /^{86} \mathbf{S r}$ & ${ }^{87} \mathbf{S r} /{ }^{\beta /} \mathbf{S r}$ \\
\hline 12483 & BR-JC-1 1 A & 96.4 & 222.3 & $1.261 \pm 0.035$ & $0.75788 \pm 0.00006$ \\
12484 & BR-JC-1 IF & 103.1 & 270.7 & $1.107 \pm 0.031$ & $0.75297 \pm 0.00006$ \\
12485 & BR-JC-11H & 90.5 & 272.6 & $0.964 \pm 0.027$ & $0.74492 \pm 0.00006$ \\
12486 & BR-JC-11 I & 128.0 & 220.8 & $1.689 \pm 0.047$ & $0.77529 \pm 0.00008$ \\
12487 & BR-JC-10A & 130.6 & 174.7 & $2.182 \pm 0.061$ & $0.79531 \pm 0.00008$ \\
\hline
\end{tabular}


Table 5-Pb-Pb analytical data on zircons from gneiss-migmatitic and granitic rocks of the Gavião Block (GB)

Tabela 5- Dados isotó picos $\mathrm{Pb}-\mathrm{Pb}$ obtidos por evaporação de monocristais de zircao.

\begin{tabular}{|c|c|c|c|c|}
\hline $\begin{array}{c}\text { SAMPLE/N } \\
\text { ZIRCON }\end{array}$ & N $^{0}$ BLOCK & ${ }^{204} \mathbf{P b} /^{206} \mathbf{P b} \pm$ error & ${ }^{207} \mathrm{~Pb} /{ }^{2066} \mathrm{~Pb} \pm$ error & AGE $(\mathrm{Ma}) \pm$ error \\
\hline BR-JC-02/9 & 3 & $0.000320 \pm 0.000169$ & $0.270965 \pm 0.001981$ & $3312 \pm 11$ \\
\hline BR-JC-02/11 & 5 & $0.000470 \pm 0.000097$ & $0.243217 \pm 0.008819$ & $3145 \pm 58$ \\
\hline BR-JC02/14 & 9 & $0.000341 \pm 0.000092$ & $0.264690 \pm 0.010711$ & $3283 \pm 63$ \\
\hline BR-JC-02/18 & 7 & $0.000257 \pm 0.000094$ & $0.273600 \pm 0.05805$ & $3329 \pm 33$ \\
\hline BR-JC-02/19 & 17 & $0.000368 \pm 0.000064$ & $0.271471 \pm 0.002723$ & $3316 \pm 16$ \\
\hline BR-JC-02/22 & 11 & $0.000134 \pm 0.000046$ & $0.280014 \pm 0.003920$ & $3365 \pm 22$ \\
\hline BR-JC-02/26 & 15 & $0.000072 \pm 0.000030$ & $0.258687 \pm 0.002415$ & $3240 \pm 15$ \\
\hline BR-JC-02/16 & 31 & $0.000157 \pm 0.000017$ & $0.211181 \pm 0.001271$ & $2916 \pm 10$ \\
\hline BR-JC-02/28 & 24 & $0.000195 \pm 0.000077$ & $0.209844 \pm 0.001647$ & $2906 \pm 13$ \\
\hline BR-JC-16/3 & 5 & $0.000349 \pm 0.000064$ & $0.252717 \pm 0.004500$ & $3203 \pm 28$ \\
\hline BR-JC-16/4 & 4 & $0.000186 \pm 0.000075$ & $0.241810 \pm 0.003333$ & $3132 \pm 22$ \\
\hline BR-JC-16/6 & 34 & $0.000141 \pm 0.000016$ & $0.241319 \pm 0.001141$ & $3129 \pm 8$ \\
\hline BR-JC-16/8 & 7 & $0.000467 \pm 0.000040$ & $0.247401 \pm 0.001857$ & $3169 \pm 12$ \\
\hline BR-JC-16/9 & 17 & $0.0004000 \pm 0.00038$ & $0.251358 \pm 0.003980$ & $3196 \pm 25$ \\
\hline BR-JC-178/4 & 12 & $0.000095 \pm 0.000011$ & $0.251506 \pm 0.001130$ & $3195 \pm 7$ \\
\hline BR-JC-178/5 & 13 & $0.000254 \pm 0.000048$ & $0.256370 \pm 0.002595$ & $3226 \pm 17$ \\
\hline BR-JC-178/7 & 5 & $0.000333 \pm 0.000549$ & $0.257015 \pm 0.003422$ & $3229 \pm 21$ \\
\hline BR-JC-178/8 & 10 & $0.000170 \pm 0.000051$ & $0.252490 \pm 0.002285$ & $3201 \pm 14$ \\
\hline
\end{tabular}

and are formed by plagioclase (30-63\%) - oligoclase and andesine - deformed, saussuritized tabular crystals, quartz $(20-35 \%)$, microcline $(0-25 \%)$, biotite $(4-9 \%)$, muscovite $(0-$ $10 \%$, and as accessory minerals apatite, titanite, epidote, sericite and zircon. Granitic-granodioritic compositions are constituted essentially by plagioclase (30-37\%), K-feldspar $(20-30 \%)$, quartz $(25-35 \%)$, biotite $(2-7 \%)$, titanite $(1-2 \%)$, and as accessory minerals apatite, epidote, zircon and opaque minerals.

Amphibolitic enclaves are common in these terranes, and apparently result from the break-up of mafic dikes during deformation. Enclaves of gneissic rocks of tonalitictrondhjemitic composition are also found and may be relicts of BG most primitive crust. Restricted granitic bodies concordant with the gneissic banding are also present, together with granitic and pegmatitic dikes and inclusions and/or remnants of supracrustal rocks.

In structural terms, these terranes present polycyclic tectono-metamorphic evolution, typical of the CSF Archaean terranes, where multiple deformation and metamorphism events are identified (Figueiredo \& Barbosa 1993). Regionally, at least three fold phases and three shear events are recognized in $\mathrm{BG}$, besides an older deformational event which produced the gneissic banding that corresponds to the Fn phase (Cunha \& Fróes 1994).

The nature of the migmatization phenomena associated with the deformations present in these terranes reveals variable patterns, from portions totally or partially preserved from migmatization to areas affected by total anatexis. The most frequent migmatitic structures are stromatic, venitic and schlieren. These migmatites are delineated by varied arrangements of leucosomatic mobilized features, apparently related to two anatexis generations. The oldest is represented by more sodic, granodioritic to trondhjemitic composition, and are formed essentially by plagioclase $(62-75 \%)$, quartz $(10-25 \%)$ and biotite (1-15\%). The youngest is potassic, composed essentially by alkaline feldspar and quartz. This second migmatization phase is linked with Transamazonic tectono-metamorphic events and therefore will not be addressed in this work.

Granitoids The Lagoa da Macambira granite is located south of the city of Brumado (Fig. IB). This body presents a slightly oval shape, homogeneous structure, is light gray, fine-grained and slightly foliated. Partially digested enclaves from the gneissic-migmatitic terranes are present, which suggest their involvement in the granite genesis. The GLM mineral composition is plagioclase $(\approx 55 \%)$, quartz $(\approx 25 \%)$, microcline $(\approx 45 \%)$, biotite + muscovite $(\approx 5 \%)$, epidote $(\approx 2 \%)$, and apatite and zircon as accessory minerals.

More expressive than the Lagoa da Macambira granite is the Malhada de Pedras biotite granodiorite, situated close to the Malhada de Pedras district (Fig. IB). It varies from light gray to light pink, is medium- to coarse-grained, porphyritic, foliated and sometimes lineated, especially when it is affected by the regional shear zones. Enclaves of migmatized gray orthogneisses and mafic rocks are also common. The rockforming minerals are plagioclase $(\approx 61 \%)$, quartz $(\approx 20 \%)$, biotite $(\approx 12 \%)$, microcline $(\approx 7 \%)$, and opaque minerals, zircon and titanite are accessories. Plagioclase crystals have tabular and lath shapes varying from 2.0 to $7.0 \mathrm{~mm}$, whereas biotite occurs as well-developed crystal agglomerates.

GEOCHEMISTRY AND GEOCHRONOLOGY GneisSiC-Migmatitic Rocks The average major element compositions of the BG gneiss-migmatitic terranes of tonalitictrondhjemitic composition (analyses n. 1-8, Table 1) are similar to those of the Archaean tonalitic-trondhjemitic-granodioritic terranes (TTG) from other continents (e.g. Condie 1981, Martin 1994). On the other hand, the rocks of graniticgranodioritic compositions (Granite-Gneiss-GG, analyses $n$. 9-12) are chemically similar to the Archaean calc-alkaline granites (e.g. Sylvester 1994).

Chemical differences between TTG and GG terranes are significant in terms of major elements. The former present lower contents and ample variation of silica $\left(68.2 \% \mathrm{SiO}_{2}\right.$ $76.8 \%$ ) and higher alumina contents (average $\mathrm{Al}_{2} \mathrm{O}_{3}=$ $15.2 \%)$, when compared to the second group $\left(73.2 \% \mathrm{SiO}_{2}\right.$ $78.6 \%$ and average $\mathrm{Al}_{2} \mathrm{O}_{3}=13.1 \%$ ). Both data sets present low ferromagnesian contents $\left(\mathrm{Fe}_{2} \mathrm{O}_{3}+\mathrm{MgO}+\mathrm{TiO}_{2}\right.$ 5.5) and negative $\mathrm{Al}_{2} \mathrm{O}_{3}-\mathrm{SiO}_{2}$ correlation (Table 1). Striking differences are given by the lower $\mathrm{K}_{2} \mathrm{O} / \mathrm{Na}_{2} \mathrm{O}$, FeaOs/MgO and $\mathrm{Al}_{2} \mathrm{O}_{3} / \mathrm{TiO}_{2}$ ratios and $\mathrm{mg} \#$ values for TTG in relation to $\mathrm{GG}$.

These chemical differences are enhanced when plotted in the Ab-An-Or diagram (O'Connor 1965, Figure 2), where it is observed that the majority of TTG samples occupies the trondhjemite field. Two samples from outcrops with high rates of felsic mobilized features (analyses n. 2 and 8) plot in the granite field of the Ab-An-Or diagram, as do all GG samples. 
The chemical differences observed for both groups of gneissic rocks (TTG and GG) are greater when trace element compositions are analyzed. The average values of the $\mathrm{Rb} / \mathrm{Sr}$ and $\mathrm{Th} / \mathrm{U}$ ratios in the TTG are lower and $\mathrm{Sc} / \mathrm{Hf}, \mathrm{Zr}$ and $\mathrm{Y}$ are higher than those of the GG. The trace element distribution patterns show slight positive $\mathrm{P}$ and $\mathrm{Zr}$ anomalies and negative $\mathrm{Ba}$, Ta and Ti anomalies for TTG (Fig. 3A), whereas higher LREE contents are found for GG, besides strong positive Th, $\mathrm{Nd}$ and $\mathrm{Tb}$ and negative $\mathrm{Sr}$ and $\mathrm{Ti}$ anomalies (Fig. 3B). The $\mathrm{Ti}$ anomaly may be linked with crustal contamination phenomena and/or involvement of continental materials, whereas $\mathrm{Sr}$ anomalies possibly reflect plagioclase fractionation phenomena during the genesis of GG (e.g. Kelemen et al. 1990, Martin 1994).

The REE distribution patterns for the TTG gneisses (Fig. 4A) are typical of Archaean gneissic terranes from other continents (Sutcliffe 1993, Condie 1993, Martin 1994), char-

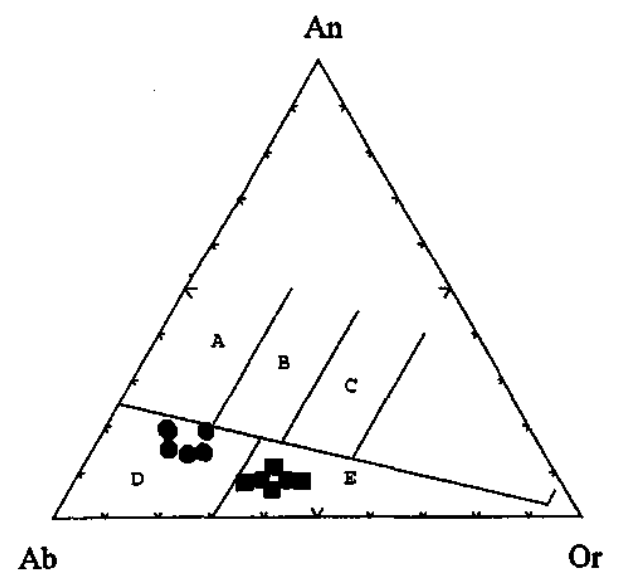

Figure 2 - Compositions of gneissic-migmatitic rocks from the Gavido Block (GB), plotted in O'Connor's (1965) diagram normative Albite (Ab) - Anorthite (An) - Orthoclase (Or). The fields are those drawn by Barker (1979). $A=$ tonalite, $B=$ granodiorite, $C=$ adamellite, $D=$ trondhjemite, $E=$ granite. $=T T G,=G G$.

Figura 2 - Composicao das rochas gnaissicas-migmatiticas do BG, com base no diagrama normativo Albita (Ab) - Anortita (An) - Ortoclásio (Or) segundo O'Connor (1965). Campos defmidos conforme Barker (1979). A = tonalito, $\mathrm{B}=$ granodiorito, $\mathrm{C}=$ adamelito, $\mathrm{D}=$ trondhjemito, $\mathrm{E}=$ granito. $=\mathrm{TTG},=$ GG.

(a)

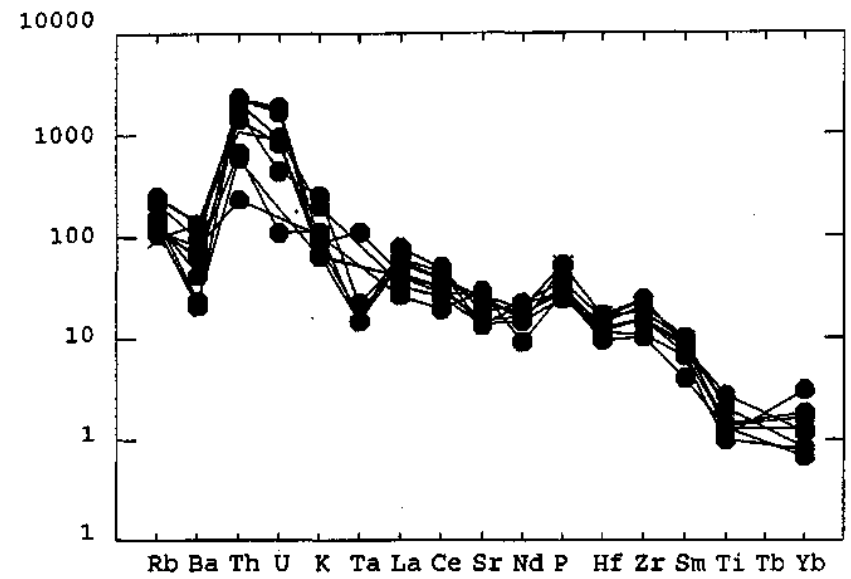

acterized by moderately high LREE $\left(\mathrm{La}_{\mathrm{N}}=83.5\right)$ and low HREE $(\mathrm{YbN}=2.5)$ contents, $(\mathrm{La} / \mathrm{Yb})_{\mathrm{N}}=33.4$, and lack of negative Eu anomaly. GG rocks differ from TTG for they present high LREE $\left(\mathrm{La}_{\mathrm{N}}=343,2\right)$ and moderate HREE $\left(\mathrm{Yb}_{\mathrm{N}}\right.$ $=47.2)$ contents and strong negative $\mathrm{Eu}$ anomaly $\left(\mathrm{Eu} / \mathrm{Eu}^{*}=\right.$ 0.3) (Fig. 4B). Such distribution is typical of Archaean TTG plutonism and post-tectonic calc-alkaline granites (e.g. Jahn et al. 1981, Martin 1987, Sylvester 1994).

In summary, the geochemical patterns observed for Archaean TTG and GG terranes of GB suggest that their total compositions were not substantially modified by migmatization, despite the multiple tectono-metamorphic events that affected these terranes during crustal evolution.

For the TTG terranes isotopic analyses by ${ }^{207} \mathrm{~Pb}^{2}{ }^{206} \mathrm{~Pb}(42$ zircon crystals) and Sm-Nd (whole rock) methods were carried out. The $\mathrm{Pb} / \mathrm{Pb}$ analyses in monozircon by evaporation were performed in a sample from a strongly migmatized outcrop (BR-JC-02) and in a gneiss sample where this migmatization phenomenon was incipient (BR-JC-178) (Table 2).

Two populations of zircons were identified in sample BR-JC-02. One is composed of well-formed (euhedral), prismatic, colorless, transparent crystals, corresponding to $c a$. $70 \%$ of the crystals present in the sample. The other population is represented by subhedral, prismatic, light brown, translucent crystals, which compose $30 \%$ of the zircon crystals present in the sample.

Initially 18 crystals from the first population were analyzed. After statistical treatment of the results and elimination of the analyses with high common lead content, data for 07 grains were used to define the age of the rock. The average plateau age obtained from 67 blocks of ${ }^{207} \mathrm{~Pb} /{ }^{206} \mathrm{~Pb}$ ratios equals $3300 \pm 45 \mathrm{Ma}$ (2o) (Fig. 5). It is assumed that this age represents the time of crystallization of the rock. Twelve grains from the second population were analyzed, from which only two were used in age calculations, vielding an average plateau age taken from 55 blocks of ${ }^{207} \mathrm{Pbr}^{206} \mathrm{~Pb}$ ratios of 2912 $\pm 10 \mathrm{Ma}$ (2a) (Fig. 6), preliminarily interpreted as the age of the first phase of migmatization.

Sm-Nd systematics points to the involvement of older continental crust in the TTG genesis, as suggested by the model age $\mathrm{T}_{\mathrm{DM}}=3.45 \mathrm{Ga}$ and $\varepsilon_{\mathrm{Nd}}=33=-1.3$ (Table 3). This data set signals continental accretion in BG coeval with the formation of Boa Vista, Sete Voltas and Mariana granitoids, located in the eastern part of BG (Martin et al. 1991, Nutman \& Cordani 1993, Santos-Pinto 1996).

In the case of sample BR-JC-178 (gneiss not affected by migmatization), large, light-brown, prismatic, euhedral, trans(b)

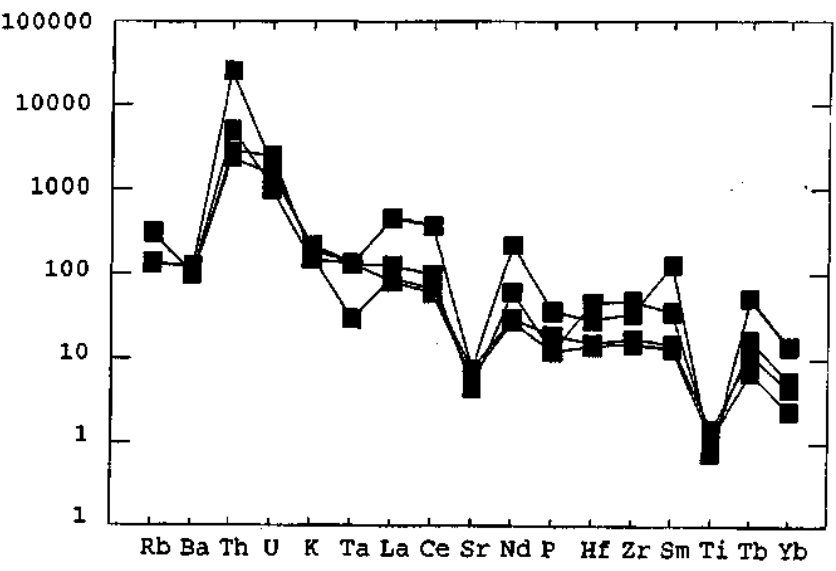

Figure 3 - Primitive mantle normalized spidergram for gneissic-migmatitic rocks from the Gavião Block (GB). (A) -Tonalitictrodhjemitic rocks and $(B)$ - Granitic-gneissic rocks $(G G)$. Normalizing values after Taylor \& McLennan (1985)

Figura 3 - Padrao compositional das rochas gnáissicas-migmatíticas do BG. (A) - Rochas tonalíticas-trondhjemíticas e (B) - Rochas granfticas-gnáissicas (GG). Valores normalizados para o manto primordial segundo Taylor \& McLennan (1985). 
(a)

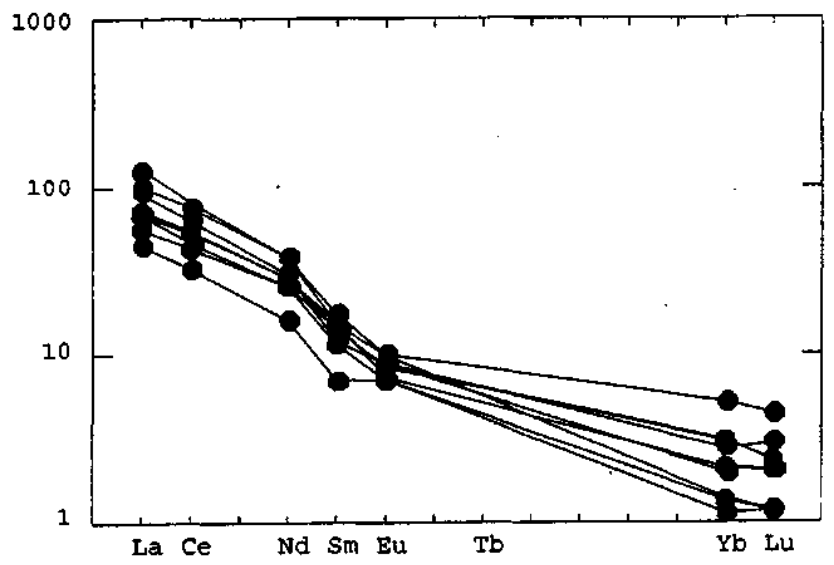

(b)

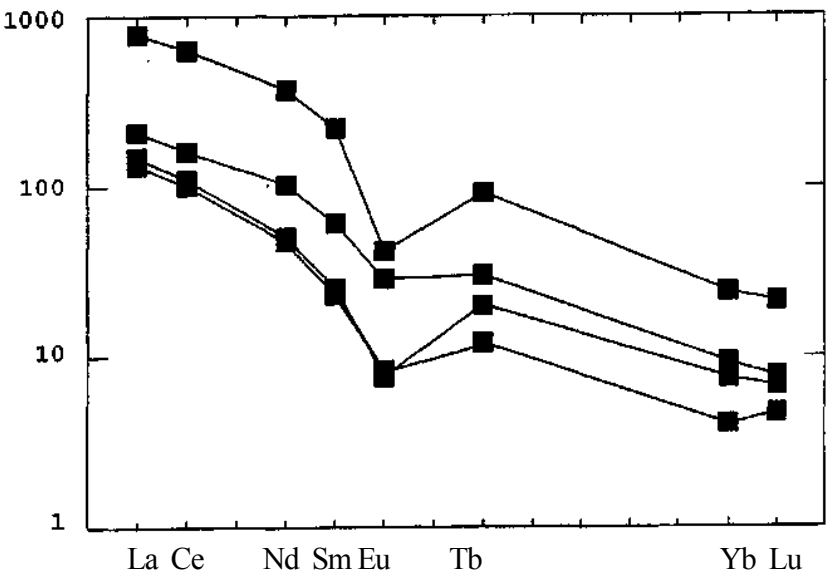

Figure 4 - Rare-earth element (REE) distribution patterns for gneissic-migmatitic rocks from the Gavião Block (GB). (A) Tonalitic-trodhjemitic rocks and (B) -Granitic-gneissic rocks (GG). Chondritic values after Taylor \& McLennan (1985).

Figura 4 - Padrao de distribute dos elementos terras raras (ETR), normalizado para condritos, para as rochas gnáissicas-migmatlicas do BG. (A) - Rochas tonaliticas-trondhjemfticas, (B) - Rochas granfticas-gnáissicas (GG).

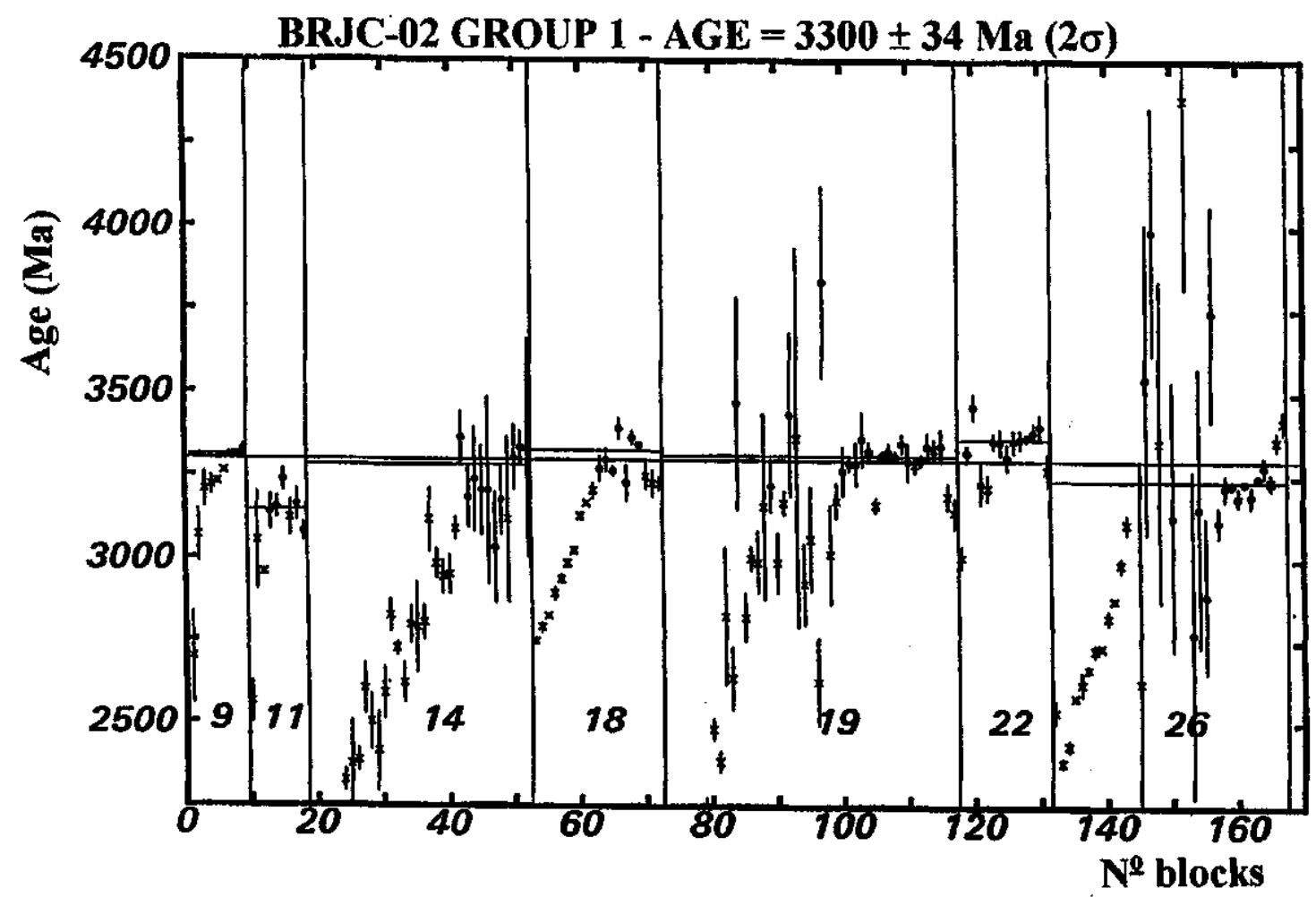

Figure 5 - Diagram age (Ma) vs. number of blocks for zircons from a gneissic-migmatitic rock sample (BR-JC-02) from the Gavião Block $(G B)$. The bar marked with " $x$ " indicates eliminated blocks. The zircon numbers are indicated.

Figura 5 - Diagrama de Idade vs. Numero de blocos de 6 razoes ${ }^{207} \mathrm{~Pb}^{206} \mathrm{~Pb}$ para zircoes dos TTG migmatizados (afloramento BR-JC-02). A barra indicada pelo "x" mostra os blocos eliminados do calculo da idade. Os numeros dos zircoes analisados São indicados.

lucent zircon crystals, usually bearing opaque minerals inclusions, were separated. Four out of twelve analyzed grains were used in the final calculations. The average plateau age obtained from 40 zircon blocks of ${ }^{207} \mathrm{~Pb} /{ }^{206} \mathrm{~Pb}$ ratios equals 3202 $\pm 15 \mathrm{Ma}$ (2o) (Fig. 7), taken as representative of the time of crystallization of these gneisses. Sm-Nd systematics yields a Sm-Nd model age $\mathrm{T}_{\mathrm{DM}}=3.6 \mathrm{Ga}$ and $\varepsilon_{\mathrm{Ndt}}=3.2 \mathrm{Ga}=-4.0$, suggesting accretion from older crustal components in the genesis of these gneisses, therefore consistent with the data from the migmatized TTG outcrop. The $\mathrm{T}_{\mathrm{DM}}$ age and the $\mathrm{Sm}-\mathrm{Nd}$ isotopic pattern obtained for these gneisses suggest that their formation took place contemporaneously with the gneisses of the Piripa region and the Lagoa do Morro/Anage granitoids, localized south and east of Brumado city respectively (Marinho 1991, Cordani et al. 1997).

Granitoids The evaluation of the chemical data (Table 2) produced for the Lagoa Macambira granite (analyses 4,5 and 6) shows patterns very similar to those for TTG rocks. This body has a low- to medium-K calc-alkaline nature, with 
narrow variations of silica $(73.0 \%<\mathrm{SiOa}<73.8 \%)$ and alumina $\left(14.8 \%<\mathrm{Al}_{2} \mathrm{O}_{3}<15.0 \%\right)$ contents, $\mathrm{CaO}=1.8-2.5 \%$ and $\mathrm{K}_{2} \mathrm{O} / \mathrm{Na}_{2} \mathrm{O} 1$ (average ratio of 0.4 ). Representative trace element ratios are $\mathrm{Rb} / \mathrm{Sr} \approx 0.3, \mathrm{Th} / \mathrm{U} \approx 7.5$ and $\mathrm{Sc} / \mathrm{Hf} \approx 0.7$. Their total composition is also very similar to the Archaean granitic-gneissic terranes (Fig. 8). On the other hand, the REE distribution pattern is strongly fractionated $(\mathrm{La} / \mathrm{Yb})_{\mathrm{N}}=48$, with lack of negative Eu anomaly (Fig. 9).

The Malhada de Pedras biotite granodiorite has a mediumto high-K calc-alkaline nature and some chemical similarities with the Archaean granitic-gneissic terranes (GG) of the BG. Silica contents vary between $71,9 \%<\mathrm{SiO}_{2}<15.0 \%$, alumina $13.6 \%<\mathrm{Al}_{2} \mathrm{O}_{3}<15,2 \%$ and $\mathrm{K}_{2} \mathrm{O} / \mathrm{Na}_{2} \mathrm{O} * 0.9$ (Table 2; analyses 1,2 and 3$)$. However, they present higher values of $\mathrm{K}_{2} \mathrm{O}(3.7), \mathrm{Rb}(\approx 104.3)$ and $\mathrm{Ba}(* 491.7)$, and lower values of $\mathrm{CaO}(\sim 1.6)$ and $\mathrm{Cs}(\approx 0.9)$ compared to $\mathrm{GG}$ and the Lagoa Macambira granite, besides negative Ta anomaly (Fig. 9). Their REE distribution pattern is very similar to that presented for the Lagoa da Macambira granite, with high fractionation $(\mathrm{La} / \mathrm{Yb})_{\mathrm{N}}=84$, differing from the latter in slightly higher LREE contents (Fig. 10).

For the Lagoa da Macambira granite, ${ }^{207} \mathrm{~Pb} /{ }^{206} \mathrm{~Pb}$ analyses were initially carried out in 12 transparent, euhedral, colorless, prismatic zircon crystals. After statistical treatment of the data and elimination of those analyses with high common $\mathrm{Pb}$ content, the results for 05 crystals were used to define the age of the rock. The average plateau age obtained from 67 blocks of ${ }^{207} \mathrm{~Pb} /{ }^{206} \mathrm{~Pb}$ ratios equals $3146 \pm 24 \mathrm{Ma}$ (2a) (Fig. 11), which represents the time of intrusion in the continental crust. This age is comparable to those obtained for Serra do Eixo and Sete Voltas gneissic rocks, located east of Brumado city (Martin et al. 1991, Santos-Pinto 1996). Sm-Nd systematics yields a model age $\mathrm{T}_{\mathrm{DM}}=3.34 \mathrm{Ga}$ and $\varepsilon_{\mathrm{Ndt}}=3.15 \mathrm{Ga}=-1.8$. This slightly negative parameter signals the contribution of a component with short crustal residence.

In addition, five samples from two contiguous outcrops (BR-JC-10 and BR-JC-11) in the Malhada de Pedras biotite granodiorite were analyzed by the Rb-Sr method. The analyti- cal results (Table 4) allowed the definition of an isochron with a $2839 \pm 134 \mathrm{Ma}$ age $(\mathrm{MSWD}=0,6)$ and ${ }^{87} \mathrm{Sr}{ }^{86} \mathrm{Sr}$ initial ratio of 0,706 (Fig. 12), interpreted as the intrusion age. The high initial ratio obtained suggests a significant participation of continental material in the genesis of this granitoid, in accordance with a more evolved geochemical pattern of this rock compared to the Lagoa Macambira granite. This interpretation agrees with $\mathrm{Sm}-\mathrm{Nd}$ evidence that yield $\varepsilon_{\mathrm{Ndt}}={ }_{2} .8 \mathrm{Ga}=-6.2$ and model age $\mathrm{T}_{\mathrm{DM}}=3.27 \mathrm{Ga}$ (Table 2). This model age is comparable with that of Lagoa da Macambira granite, which suggests the involvement of crustal materials in the genesis of these granites.

DISCUSSION AND CONCLUSIONS The Gavião Block (BG) presents a polyphase geologic evolution, with recurrence of Archaean magmatic and tectono-thermal events during the Paleo- and NeoArchaean (Table 6). Although field observations do not allow the establishment of a relative chronology between the different plutonic events in $\mathrm{BG}$, the ages obtained by $\mathrm{Rb}-\mathrm{Sr}, \mathrm{Pb}-\mathrm{Pb}$ and $\mathrm{U}-\mathrm{Pb}$ methods indicate the recurrence of Archaean granitoid intrusions with age intervals varying ca. $50 \mathrm{Ma}$.

The BG primitive evolution is represented by the formation of Sete Voltas, Boa Vista/Mata Verde and Bernarda massifs, whose differentiation occurred $c a$. 3.4-3.3 Ga ago (Martin et al. 1991,Nutman\&Cordani 1993, Santos-Pinto 1996). Moreover, the $\mathrm{Sm}-\mathrm{Nd}$ model ages $\left(\mathrm{T}_{\mathrm{DM}}\right)$ for these granitoids present values varying between $3.3-3.7 \mathrm{Ga}$, while $\varepsilon_{\mathrm{Nd}(\mathrm{t})}$ values vary between +3.0 and -5.9 (Martin et al. 1991, Marinho et al. 1992, Santos-Pinto 1996), suggesting the involvement of older protoliths, still not identified in the CSF northern portion.

After the formation of the BG primitive crust, several episodes of TTG and granitic plutonism are registered in this crustal segment, with ages varying between 3.3-3.1 Ga (Martin et al. 1991, Marinho et al. 1992, Santos-Pinto et al. 1995, Cunha et al. 1996, Bastos Leal et al. 1996). In this scenario, the gneissic-migmatitic (TTG), granitic-gneissic (GG) rocks

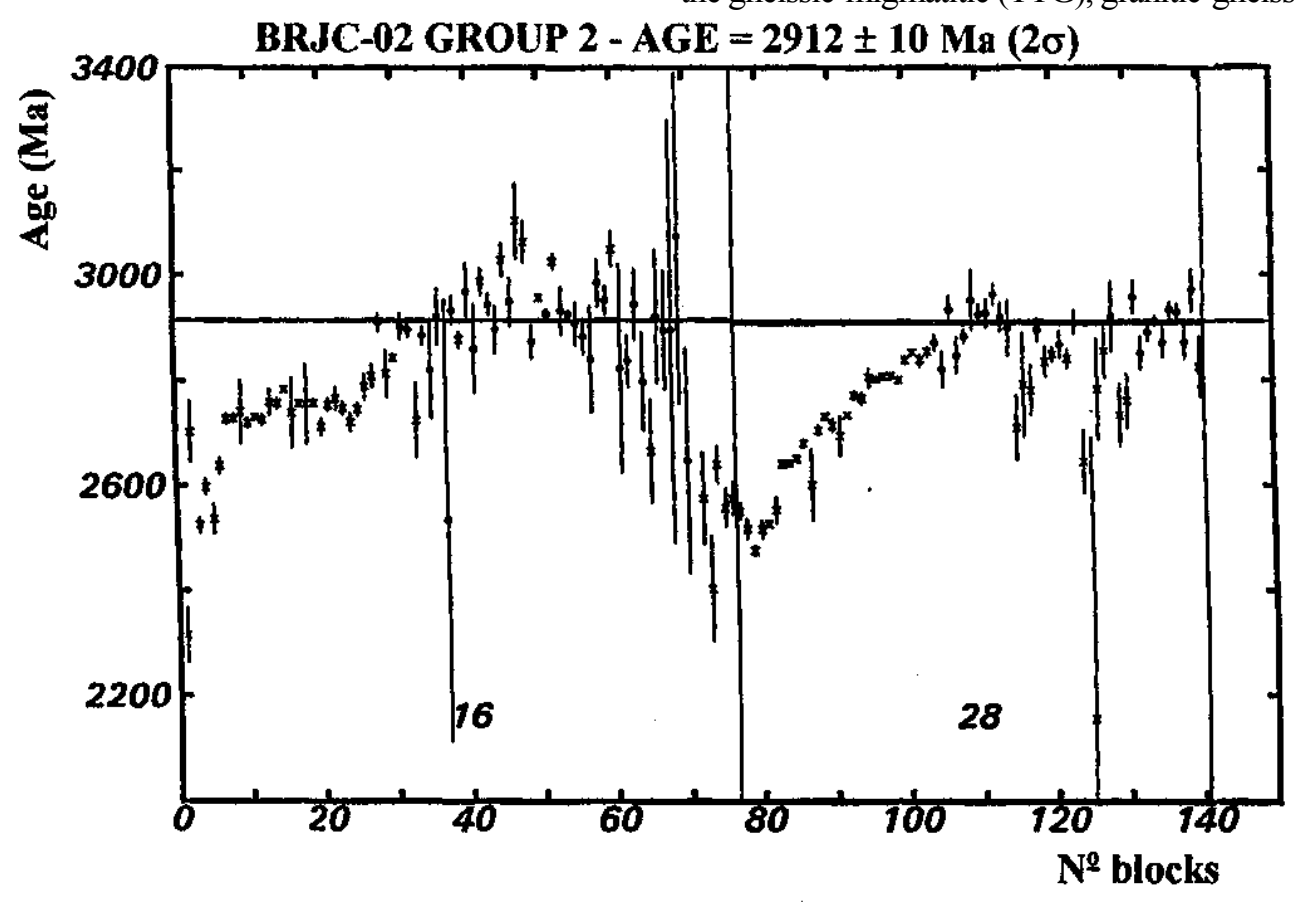

Figure 6 - Diagram age (Ma) vs. number of blocks for zircons from a gneissic-migmatitic rock sample (BR-JC-02) from the Gavião Block $(G B)$. The bar marked with on " $x$ " indicates eliminated blocks. The zircon numbers are indicated.

Figura 6 - Diagrama de Idade vs. Número de blocos de 6 razões ${ }^{207} \mathrm{~Pb}{ }^{206} \mathrm{~Pb}$ para zircões dos TTG migmatizados (afloramento BR-JC- $0_{2}$ ). A barra indicada pelo "x" mostra os blocos eliminados do cálculo da idade. Os números dos zircões analisados são indicados. 


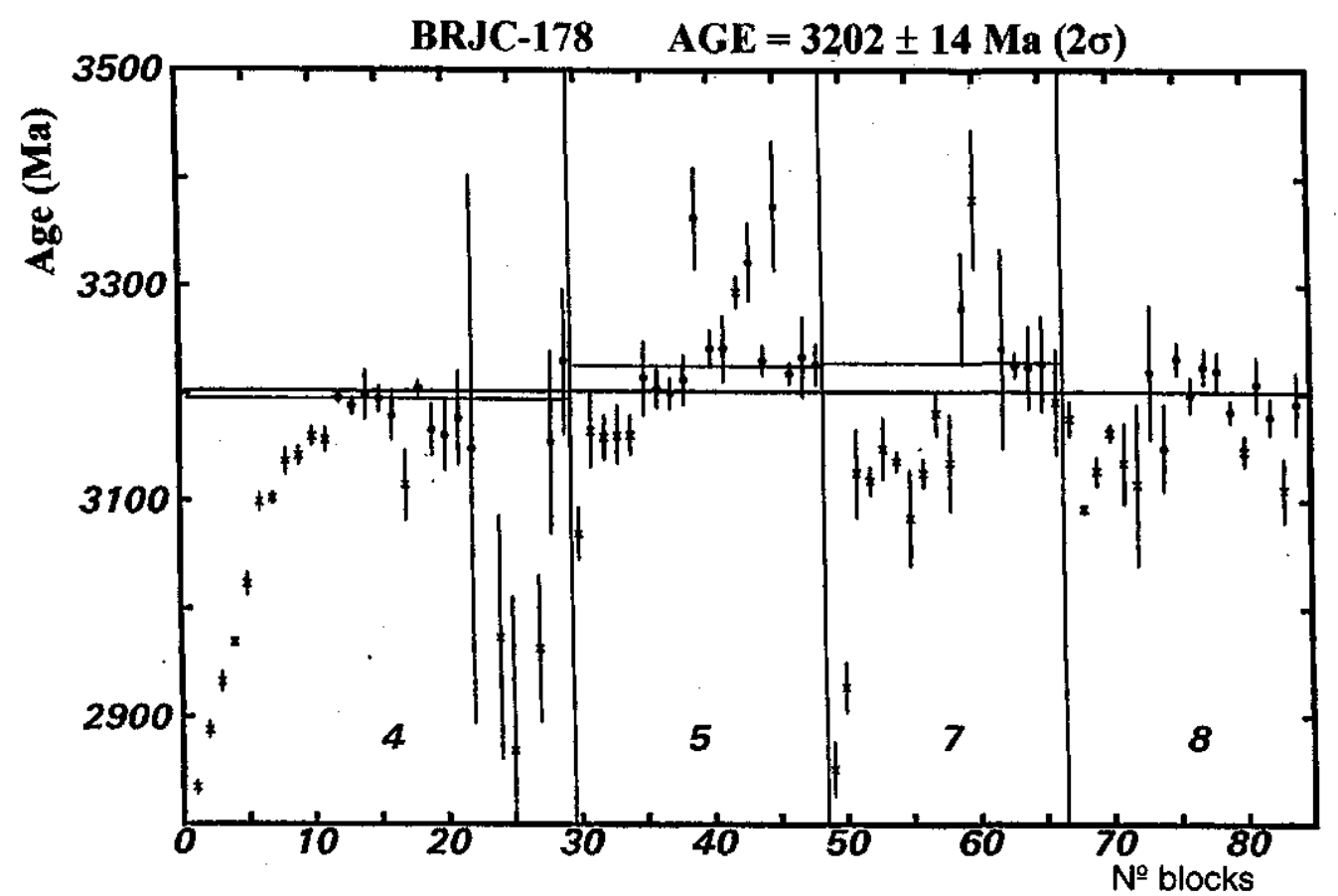

Figure 7 - Diagram age (Ma) vs. number of blocks for zircons from a gneissic rock sample (BR-JC 178) from the Gavido Block (GB). The bar marked with on " $x$ " indicates eliminated blocks. The zircon numbers are indicated.

Figura 7 - Diagrama de Idade vs. Numero de blocos de 6 razoes ${ }^{207} \mathrm{~Pb}{ }^{206} \mathrm{~Pb}$ para zircoes dos TTG sem migmatização (afloramento BR-JC-178). A barra indicada pelo "x" mostra os blocos eliminados do calculo da idade. Os numeros dos zircoes analisados São indicados.

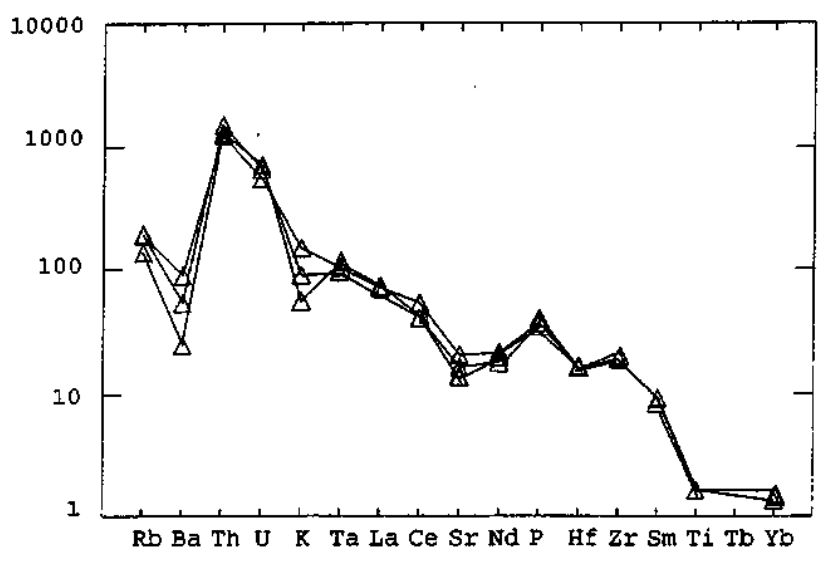

Figure 8 - Primitive mantle normalized spidergram for the Lagoa Macambira granite. Normalizing values after Taylor \& McLennan (1985).

Figura 8 - Composição do granite de Lagoa da Macambira. Valores normalizados para o manto primordial segundo Taylor \& McLennan (1985).

and the Lagoa da Macambira granite appear as representatives of this granite genesis of calc-alkaline nature, thus suggesting processes analogous to plate tectonics. This interpretation is corroborated by $\varepsilon_{\mathrm{Nd} d(t)}$ values (varying between +0.4 and -4.0 ) which point to differential recycling of primitive continental crust. Similar evolutionary crustal pattern of the Archaean crust has been suggested for several granitoids (e.g. Serra do

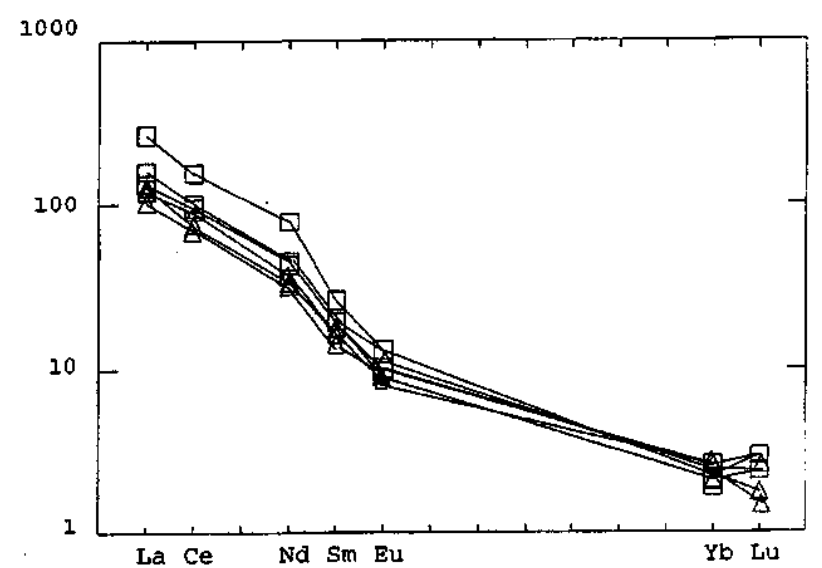

Figure 9 - Primitive mantle normalized spidergram for Malhada Pedras granite. Normalizing values after Taylor \& McLennan (1985).

Figura 9 - Composição dos granites de Malhada de Pedras. Valores normalizados para o manto primordial segundo Taylor \& McLennan (1985).

Eixo, Sete Voltas, Mariana, Aracatu etc,) from the BG eastern segment (Martin et al. 1991, Santos-Pinto 1996). In this context, the Lagoa da Macambira granite belongs to an ample granitic event that occurred in BG around 3.15 Ga ago.

The Archaean ages obtained for the TTG terranes from BG, together with those obtained for detrital zircons from the Jacobina belt (north of CSF) and the Umburanas greenstone 
belt (Mougeot et al. 1996, Bastos Leal et al. 1996), indicate that the Archaean magmatic processes occurred mainly between 3.4-3.0 Ga. As a consequence and extrapolating the area presently exposed, BG played the role of formation a huge continental mass $c a$. 3.0 Ga ago, with approximately 35,000 $\mathrm{km}^{2}$, comparable in size with other Archaean continental segments (Pilbara and Yilgarn blocks in Australia and the Superior Province in Canada).

There is a strong evolutionary contrast in the paleogeography and evolution between BG and the Jequié Block $(2.9 \mathrm{Ga})$,

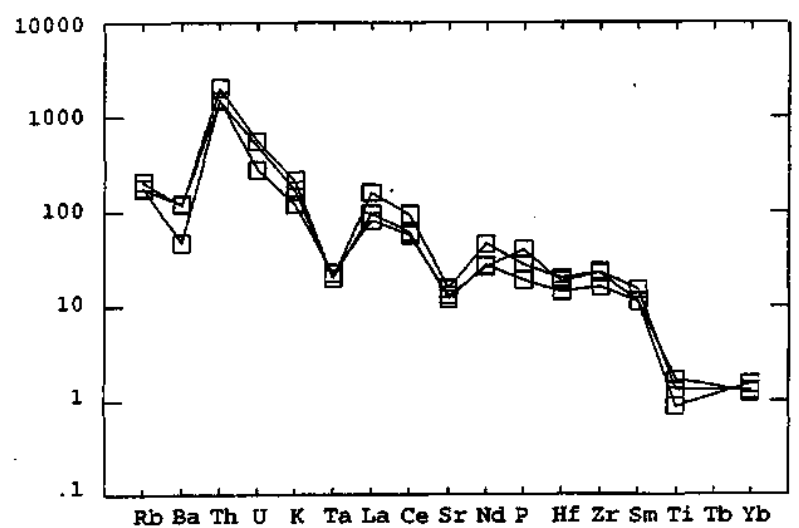

Figure 10 - REE distribution patterns for Lagoa Macambira (triangle) and Malhada de Pedras (square) granite. Chondritic values after Taylor \& McLennan (1985). Figura 10 - Curvas de ETR, normalizadas para condritos, dos granites de Lagoa da Macambira (triangulos) e de Malhada de Pedras (quadrados). Valores normalizados segundo Taylor \& McLennan (1985). showing that these two continental blocks might have had completely distinct geological histories during the Archaean. This interpretation is corroborated by the evolution diagram $\mathrm{Nd}(\mathrm{t})$ vs. Time $(\mathrm{Ga})$ of rocks from both domains (Fig. 13). The $\overline{\text { Sm-Nd model ages }}\left(\mathrm{T}_{\mathrm{DM}}\right)$ of the BG rocks vary between 3.2 and $3.7 \mathrm{Ga}$, with $\varepsilon_{\mathrm{Ndt}(0)}$ between -33 and -57 . In the Jequie Block, TDM values vary between $2.8-3.2 \mathrm{Ga}$ and $\varepsilon \mathrm{Nd}(0)$ between -23 and -28 , denoting that these two continental crustal segments of the South-American platform evolved in different ways.

In the MesoArchaean, the intrusion of Malhada de Pedras and Serra dos Pombos granites took place at 2.9-2.8 Ga, followed by deformation and regional metamorphism in the amphibolite facies. The chemical and isotopic ( $\mathrm{Sr}$ and $\mathrm{Nd}$ ) data suggest that the Malhada de Pedras granite originated from partial fusion of the Archaean continental crust. Also at the end of the Archaean, BG was a target for subalkaline plutonism, represented by the Pe de Serra granites with ages around 2.6 Ga (Cordani et al. 1985, Marinho 1991).

Finally, during the Palaeoproterozoic, magmatic and tectono-metamorphic events affected BG, as exemplified by intensive granite intrusion and migmatization. On the other hand, the younger ages recorded in $\mathrm{BG}(\mathrm{ca}$. 1.0-0.45 Ga) represent the role played by tectono-metamorphic events that caused partial or total resetting of the $\mathrm{Rb}-\mathrm{Sr}$ and $\mathrm{K}-\mathrm{Ar}$ isotopic systems. In particular, K-Ar ages show the effect of younger regional cooling episodes, related to the geotectonic Brasiliano Cycle.

Acknowledgments To Fundacao de Amparo a Pesquisa do Estado de São Paulo-FAPESP (Grants 94/0999-5 and 95/4652-2) and Conselho nacional de Desenvolvimento Cientifico e Tecnologico (CNPq (Grant 523486-94.4) for the financial support to this research. To Companhia Baiana de Pesquisa Mineral-CBPM for the field work support and funds for the ${ }^{207} \mathrm{~Pb} /{ }^{206} \mathrm{~Pb}$ isotopic analyses. To geologists Juracy $\mathrm{F}$. Mascarenhas and Moacir M. Marinho, as well as to two anonymous referees of RBG for their valuable suggestions.

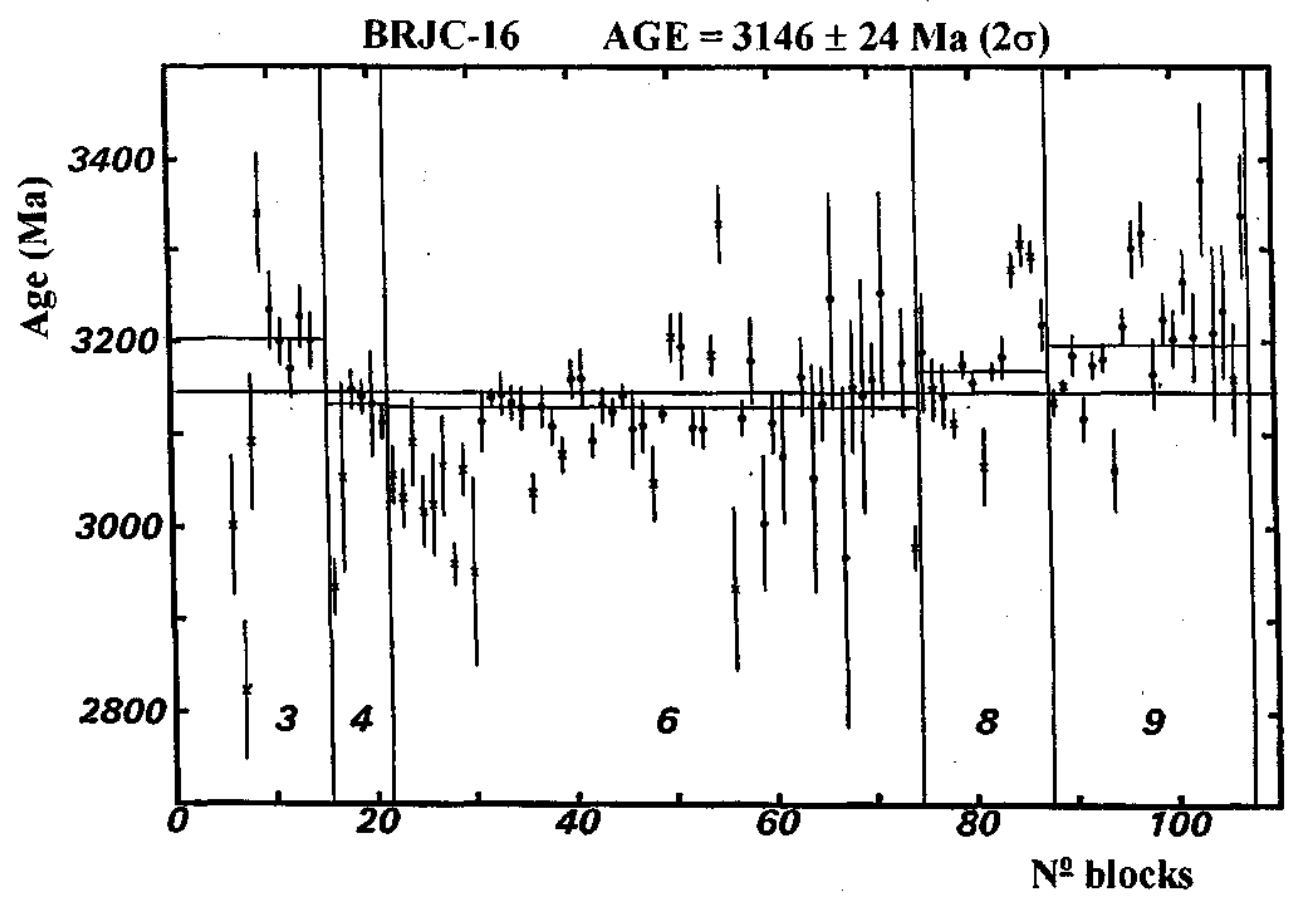

Figure 11 - Diagram age (Ma) vs. number of blocks for zircons of the Lagoa de Macambira granite. The bar marked with on " $x$ " indicates eliminated blocks. The zircon numbers are indicated.

Figura 11 - Diagrama de Idade vs. Número de blocos de 6 razões ${ }^{207} \mathrm{~Pb} /{ }^{206} \mathrm{~Pb}$ para zircoes do granito da Lagoa da Macambira. A barra indicada pelo "x" mostra os blocos eliminados do calculo da idade. Os numeros dos zircoes analisados são indicados. 


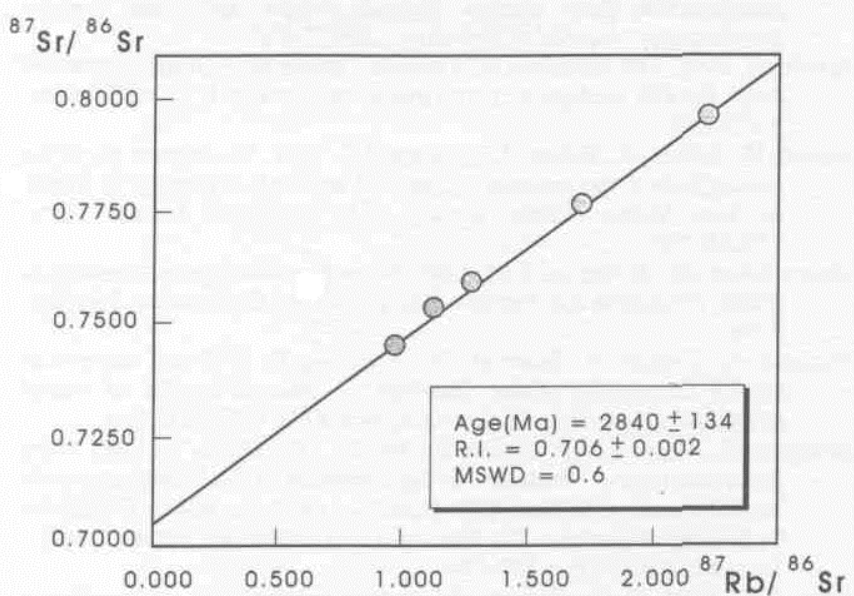

Figure 12 - Rb-Sr whole rock isochron of the Malhada de Pedras granite.

Figura 12 - Diagrama isocronico $\mathrm{Rb}-\mathrm{Sr}$ em rocha total para o granodiorito de Malhada de Pedras.

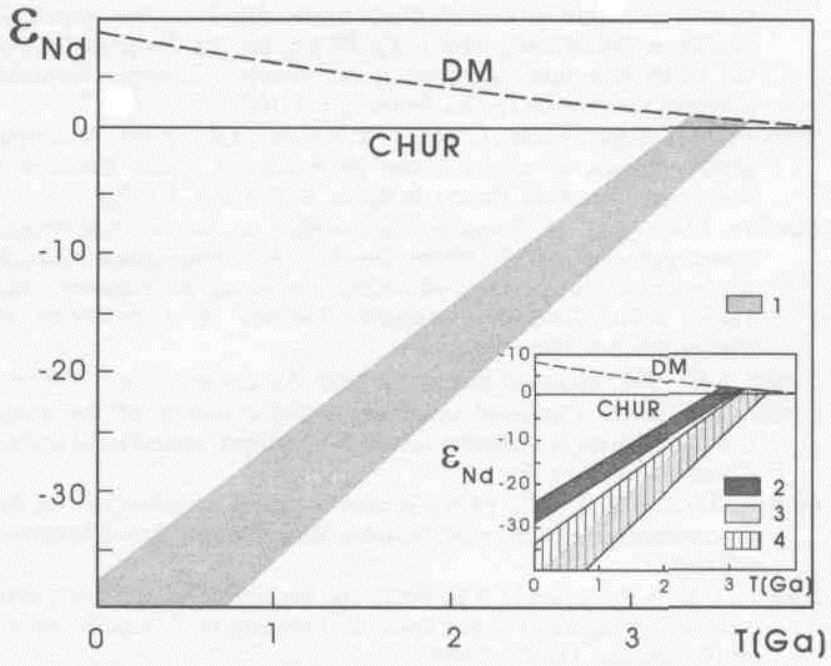

Figure 13 - Nd isotopic composition of the Gavido and Jequié blocks: (1) This work, (2) Wilson et al (1988), (3) Marinho (1991), (4) Santos-Pinto (1996).

Figura 13 - Composifao isotopica dos Blocos Gavião e Jequié: (1) Este trabalho, (2) Wilson et al. (1988), (3) Marinho (1991), (4) Santos-Pinto (1996).

Table 6 - Major Archaean magmatic and tectonothermal activity in the Gavião Block. Tabela 6 - Principais eventos magmaticos e tectonotermais arqueanos do Bloco do Gavião.

\begin{tabular}{|c|c|c|c|}
\hline Event & Age (Ma) & Methodology & References \\
\hline Intrusion of the tonalitic-trondhjemitic protoliths of Sete Voltas Massif & $3400-3390$ & U-Pb (Shrimp), ${ }^{207} \mathrm{~Pb}-{ }^{206} \mathrm{~Pb}, \mathrm{Rb}-\mathrm{Sr}$ & $1,4,6$ \\
\hline Formation of Boa Vista/Mata Verde gneissic domes & $3380-3350$ & U-Pb (Shrimp), ${ }^{207} \mathrm{~Pb}-{ }^{206} \mathrm{~Pb}, \mathrm{Rb}-\mathrm{Sr}$ & $2,5,6$ \\
\hline Intrusion of the Bernarda and Brumado tonalitic and granitic gneisses & $3330-3300$ & ${ }^{207} \mathrm{~Pb}-{ }^{206} \mathrm{~Pb}$ & $9,11,12$ \\
\hline $\begin{array}{l}\text { Intrusion of trondhjemites, monzogranites and granodiorites of Mariana, Aracatu and Sete } \\
\text { Voltas }\end{array}$ & $3250-3240$ & ${ }^{207} \mathrm{~Pb}-{ }^{206} \mathrm{~Pb}$ & 5,9 \\
\hline $\begin{array}{l}\text { Formation of komatiitic and basaltic flows of the lower unit of the Contendas-Mirante and } \\
\text { Umburanas greenstone belts }\end{array}$ & $3250-3150$ & $\mathrm{Sm}-\mathrm{Nd}\left(\mathrm{T}_{\mathrm{DM}}\right)$ & $5,7,11$ \\
\hline $\begin{array}{l}\text { Formation of detrital and chemical sediments of the lower unit of the Contendas-Mirante and } \\
\text { Umburanas greenstone belts }\end{array}$ & $3250-3150$ & $\mathrm{U}-\mathrm{Pb}$ (Shrimp), ${ }^{207} \mathrm{~Pb}-{ }^{206} \mathrm{~Pb}$ & 5,8 \\
\hline Intrusion of granite-gneisses of Rio do Antônio, Piripá and Lagoa do Morro/Anagé granitoids & $3200-3180$ & $\mathrm{U}-\mathrm{Pb}$ (Shrimp), ${ }^{207} \mathrm{~Pb}-{ }^{206} \mathrm{~Pb}, \mathrm{Rb}-\mathrm{Sr}$ & $5,6,10,12$ \\
\hline $\begin{array}{l}\text { Intrusion of Serra do Eixo, Lagoa da Macambira granitoids and young gneisses of Sete Voltas } \\
\text { massif }\end{array}$ & $3160-3140$ & ${ }^{207} \mathrm{~Pb}-{ }^{206} \mathrm{~Pb}, \mathrm{Rb}-\mathrm{Sr}$ & $4,8,9,11,12$ \\
\hline $\begin{array}{l}\text { Intrusion of Serra dos Pombos and Malhada de Pedras granites, accompanied by migmatization, } \\
\text { deformation and metamorfism of amphibolite facies }\end{array}$ & $2900-2800$ & $\mathrm{U}-\mathrm{Pb}$ (Shrimp), ${ }^{207} \mathrm{~Pb}-{ }^{206} \mathrm{~Pb}, \mathrm{Rb}-\mathrm{Sr}$ & $6,8,11,12$ \\
\hline Felsic volcanism of Umburanas greenstone belt & $2750+15$ & ${ }^{207} \mathrm{~Pb}-{ }^{206} \mathrm{~Pb}$ & 7,11 \\
\hline Deformation and metamorfism of amphibolite facies & $2700-2650$ & $\mathrm{Rb}-\mathrm{Sr}$ & 1,3 \\
\hline Intrusion of Pé de Serra subalkaline granites & $2559 \pm 110$ & $\mathrm{~Pb}-\mathrm{Pb}$ (whole rock) & 5 \\
\hline Felsic volcanism of Contendas-Mirante greenstone belt & $2550-2450$ & $\mathrm{~Pb}-\mathrm{Pb}$ (whole rock), $\mathrm{Rb}-\mathrm{Sr}$ & 5 \\
\hline 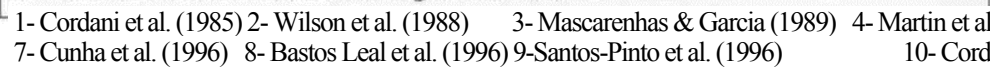 & $\begin{array}{l}\text { (1991) } \\
\text { hi et al. (1997) }\end{array}$ & $\begin{array}{l}\text { 5- Marinho (1991) 6- Nutman \& C } \\
11 \text { - Bastos Leal et al. (1997) } \quad \text { 12- Th }\end{array}$ & $\begin{array}{l}\operatorname{ani}(1993) \\
\text { rork }\end{array}$ \\
\hline
\end{tabular}

\section{REFERENCES}

Alkmin, F.F.; Brito Neves, B.B. ; Castro Alves, J.A. 1993. Arcabou90 tectonico do Craton do São Francisco: Uma ReviSão. In: Dominguez, J.M.L. \& Misi, A. eds. O Craton do São Francisco, Salvador, Brazil SBG/SGM/CNPq, p.45-62.

Barbosa, J.S.F. 1990. The granulites of the Jequie Complex and Atlantic Mobile Belt, Southern Bahia, Brazil - An expression of Archaean Proterozoic plate convergence. In: Granulites and Crustal Evolution. Vielzeuf, D. \& Vidal, P.H. eds. Springer-Verlag, 585p.

Barbosa, J.S.F.; Marinho, M.M.; Sabate, P. 1992. Geology of the Jequie-Itabuna granulitic belt, In: Pedreira, A.J. ed. Petrologic and geochronologic evolution of the oldest segments of the Sdo Francisco Craton, Brazil. IGCP Project 280, p. 7-28.

Barbosa, J.S.F. \& Dominguez, J.M.L. 1996. Mapa geologico do estado da Bahia. Texto Explicativo, SICM7SGM, 382p.
Barker, F. 1979. Trondhjemite: definition, environment and hypothesis of origin, In: Barker, F. ed. Trondhjemimites, dacites, and related rocks, Amsterdam, Elsevier, p 1-12.

Bastos Leal, L.R. \& Teixeira, W. 1994. Investigacao geocronologica dos terrenos granito-gnaisse do Bloco Gavião, Craton do São Francisco Resultados Parciais. In: Congresso Brasileiro de Geologia, 38, Balneario Camboriu 1994. Anais... Balneario de Camboriii, SBG, v. 5, p.74-75.

Bastos Leal, L.R. \& Teixeira, W.; Macambira, M.J.B.; Cordani, U.; Cunha, J.C. 1996. Evolufao crustal dos terrenos TTGs arqueanos do Bloco do Gavião, Craton do São Francisco: Geocronologia U-Pb (Shrimp) e $\mathrm{Pb}-\mathrm{Pb}$ em zircoes. In: Congresso Brasileiro de Geologia, 39, Salvador 1996, Anais... Salvador, SBG, v. 6, p.539-541. 
Bastos Leal, L.R.; Teixeira, W.; Cunha, J.C.; Macambira, M.J.B. 1997. Crustal evolution of Gavião block of the São Francisco craton: A geochronological study with $\mathrm{U}-\mathrm{Pb}, \mathrm{Pb}-\mathrm{Pb}, \mathrm{Sm}-\mathrm{Nd}, \mathrm{Rb}-\mathrm{Sr}$ and $\mathrm{K}-\mathrm{Ar}$. In: South-American Symposium on Isotope Geology, Extended Abstract, Campos do Jordao, Brasil, p.161-162.

Brito Neves, B.B.; Cordani, U.G.; Torquato, J.R. 1980. Evolu?ao geocronologica do precambriano do estado da Bahia, Geologia e Recursos Minerals do Estado da Bahia, SME-CPM, 3:1-101.

Carneiro, M.A. 1992. O Complexo metamórfico do Bonfim Setentrional (Quadrilatero Fernfero, Minus Gerais): Litoestratigrafia e evolucao geologica de urn segmento de crosta continental do Arqueano, São Paulo, 232p (Tese de doutorado, Institute de Geociencias da Universidade de São Paulo).

Condie, K.C. 1981. Archaean greenstone belts. Amsterdam, Elsevier, 434p.

Condie, K.C. 1993. Chemical composition and evolution of the upper continental crust: contrasting results from surface samples and shales. Chemical Geology 104:1-37.

Cordani, U.G. \& lyer, S.S. 1979. Geochronological investigation on the precambrian granulitic terrain of Bahia, Brazil. Precambrian Research, 9:255-274.

Cordani, U.G. \& Brito Neves, B.B. 1982. The geological evolution of South America during the Archaean and Early Proterozoic. Revista Brasileira de Geociencias 12(1/3):78-88.

Cordani, U.G.; Sato, K.; Marinho, M..M. 1985. The geologic evolution of the ancient granite-greenstone terrain of central-southern Bahia, Brazil Precambrian Research, 27:187-213.

Cordani, U.G.; Sato, K.; Coutinho, J.M.V.; Nutman, A. 1997 Geochronological interpretation in areas with complex geological evolution: The case of Piripa, central-southern Bahia, Brazil. In: South-American Symposium on Isotope Geology, Extended Abstracts, p. 85-87.

Cunha, J.G. \& Froes, R.J.B. 1994. Komatiftos com textura spinifex do greenstone belt de Umburanas, Bahia. Serie Arquivos Abertos. Companhia Baiana de Pesquisa Mineral -CBPM, Salvador 1994. 29p.

Cunha, J.C.; Bastos Leal, L.R.; Fr6es, R.J.B.; Teixeira, W.; Macambira, M.J.B 1996. Idade dos greenstone belts e dos terrenos TTG's associados da regiao de Brumado centro-oeste do Craton do São Francisco (Bahia - Brasil), In: Congresso Brasileiro de Geologia, 39, Salvador 1996, Anais... Salvador. SBG, v. 1, p.67-70.

DePaolo, D.J. 1988. Neodymium isotope geochemistry. An introdution $187 \mathrm{p}$. Springer-Varlag 1988.

Figueiredo, M.C.H. \& Barbosa, J.S.F. 1993. Terrenos metamorficos de alto grau do Craton do São Francisco, In: Dominguez, J.M.L. \& Misi, A eds. O Craton do São Francisco. Salvador, SBG/SGM/CNPq, p.63-84.

Fr6es, R.J.B.; Lopes, G.A.C.; Cunha, J.C. 1994. Tipologia dos granitoides associados ao greenstone belt de Umburanas e aos terrenos vulcanossedimentares de Ibitira/Brumado -Bahia, In: Congresso Brasileiro de Geologia, 38, Balneario de Camboriu 1994. Anais... Balneario de Camboriu, SBG. v. 5, p. 185-187.

Fuck, R.A.; Jardim de Sa E.F.; Pimentel, M.M.; Dardenne, M.A.; Scares, A.C.P. 1993. As faixas de dobramentos marginais do Craton do São Francisco: Smtese dos conhecimentos, In: Dominguez, J.M.L. \& Misi, A. eds. O Craton do São Francisco, Salvador. SBG/SGM/CNPq, p.161-185

Gaudette, H.E.; Lafon, J.M.; Moura, C.A.V.; Schller, T. 1993. Data9ao de monocristais de zircao por evapora?ao de $\mathrm{Pb}$ no Laboratorio de Geologia Isotopica -UFPa: Metodologia e primeiros resultados. In Congresso Brasileiro de Geoqufmica, 4, Brasilia, Anais... Brasilia. SBGq, p.236-245.

Jahn, B.M.; Glikson, A.Y.; Peucat, J.J.; Hickman, A.H. 1981. REE geochemistry and isotopic data of Archaean silicic volcanics and granitoids from the Pilbara Block, Western Australia: Implications for the early crustal evolution. Geochimica et Cosmochimica Acta, 45:1633-1652.

Kelemen, P.B.; Johnson, K.T.M.; Kinzler, R.J.; Irving, A.J. 1990. High-field-strength element depletion in arc basalts due to mantle-magma interation. Nature, 345: 521-524.

Kober, B. 1986. Whole grain evaporation for ${ }^{207} \mathrm{~Pb} /{ }^{206} \mathrm{~Pb}$-age investigations on single zircon using a double-filament thermal ion source. Contributions to Mineralogy and Petrology, 93:482-490.

Kuno, H. 1968. Differentiation of basalt magmas. In: Hess, H.H. \& Poldervaart, A. eds. The Poldevaart treatise on rocks of basaltic composition. Interscience publisher, 2:623-688.

Marinho, M.M. 1991. La Sequence Volcano-Sedimentaire de ContendasMirante et la Bordure Ocidentale du Bloc de Jequie (Craton du São Francisco, Bresil): un example de transition archeen-proterozoique, France. 257p. (PhD Thesis, Universidade de Clermont-Ferrand)

Marinho, M.M.; Sabate, P.; Barbosa, J.S.F. 1992. The Contendas-Mirante vulcano-sedimentary belt. In: Pedreira, A.J. ed. Petrologic and geochronologic evolution of the oldest segments of the São Francisco Craton, Brazil. IGCP Project 280, p. 29-75.
Martin, H. 1987. Petrogenesis of Archaean trondhjemites, tonalites and granodiorites from eastern Finland: Major and trace element geochemistry. Journal of Petrology, 28:921-953.

Martin, H. 1994. The Archaean grey gneisses and genesis of the continental crust. In: The Archaean crustal evolution. Condie, K.C. ed. Elsevier, p.205-259.

Martin, H,; Sabate, P.; Peucat, J.J.; Cunha, J.C. 1991. Un segment de croute continentale d'âge archéen ancien (3,4 milliards d'annees): le massif de Sete Voltas (Bahia, Bresil! C.R. Academic Science Paris, 313:531-538

Mascarenhas, J.F. \& Garcia, T.M. 1989. Mapa geocrono!6gico do estado da Bahia, Secretaria das Minas e Energia. Texto Explicative, Salvador, Bahia.

Michard, A.; Gurriet, P.; Sounant, M.; Albarede, F. 1985. Nd isotopes in French Fanerozoic shales: External vs. internal aspects of crustal evolution. Geochimica et Cosmochimica Acta, 49(2):601-610.

Mougeot, R.; Respaut, J.P.; Ledru, P.; Milesi, J.P.; Johan, V. 1996. U-Pb geochronological constrain for the evolution of the Paleoproterozoic Jacobina auriferous basin (São Francisco province, Bahia, Brasil), In: Congresso Brasileiro de Geologia, 39, Salvador 1996. Anais... Salvador, SBG. v.6, p.582-584.

Noce, C.M. 1995. Geocronologia dos eventos magmdticos, sedimentares e metamorficos na regiao do Quadrilátero Ferrifero, Minas Gerais. São Paulo. 128p. (Tese de Doutorado, Institute de Geociencias da Universidade de São Paulo).

Nutman, A.P. \& Cordani, U.G. 1993. SHRIMP U-Pb zircon geochronology of Archaean granitoids from the Contendas-Mirante area of the São Francisco Craton, Bahia, Brazil. Precambrian Research, 63:179-188.

O'Connor, J.T. 1965. A classification of quartz-rich igneous rocks based on feldspar ratio. U.S. Geological Survey Professional Paper, 525-6:79-84.

Rocha, G.M.F. \& Fuck, R.A. 1996. As faixas marginais dobradas do Proterozoico Superior do Craton do São Francisco. In: MapaGeologico do Estado da Bahia. Texto Explicativo, p. 127-141.

Sabate, P.; Marinho, M.M.; Vidal, P.; Vachette, M. 1990. The 2-Ga peraluminous magmatism of the Jacobina-Contendas Mirante belts (Bahia,Brazil): geologic and isotopic constraints on the sources. Chemical Geology, 83:325-338.

Santos-Pinto, M.; Peucat, J.J.; Martin, H.; Sabate, P. 1995. Petrogenesis of the oldest part of the São Francisco craton (Bahia state, Brazil): geochronology and isotopic chemistry. European Union of Geoscience meeting, Strasbourg IX-2, p. 103.

Santos-Pinto, M. 1996. Le recyclage de la croute continentale archeenne: Exemple du bloc du Gavião - Bahia, Bresil, France 193p. (Doctor of Philosophy Thesis, Geociences Rennes, France).

Ssto, K.; Cordani, U.G.; Teixeira, W. 1996. Principais epocas de acres?ao manto-crosta continental do craton de São Francisco, com base em idades modelo Sm-Nd. In: Congresso Brasileiro de Geologia, 39, Salvador 1996. Anais... Salvador, SBG. v.6, p.525-527.

Schrank, A. \& Silva, M.G. 1993. Os greenstone-belts do Craton do São Francisco, In: Dominguez, J.M.L. \& Misi, A. eds. O Craton do São Francisco, Salvador, SBG/SGM/CNPq, p.161-185

Steiger, R.H. \& Ja'ger, E. 1977. Subcomission on Geochroriology: convention on the use of decay constants in geochronology and cosmochronology. A.A.P.G. Studies in Geology, p. 67-71.

Sutcliffe, R.H.; Barrie, C.T.; Burrows, D.R.; Beakhouse, G.P. 1993. Plutonism in the southern Abitibi subprovince: A tectonic and petrogenetic framework. Economic Geology, 88:1359-1375.

Sylvester, P.J. 1994. Archaean granite plutons. In: Condie, K.C. ed. The Archaean crustal evolution. Elsevier, p. 261-314.

Taylor, S.R. \& McLennan, S.M. 1985. The continental crust: its composition and evolution. Blackwell Scientific, Oxford, $312 \mathrm{p}$.

Teixeira, W. \& Canzian, F.S. 1994. A evolução tectonotermal proterozoica do Craton do São Francisco com base em interpretacoes geocronologicas K-Ar em rochas do seu embasamento. Boletim IG-USP, Série Cientifica, 25:61-80.

Teixeira, W. \& Figueiredo, M.C.H. 1991. An outline of Early Proterozoic crustal evolution in the São Francisco craton, Brazil: a review. Precambrian Research, 53:1-22.

Teixeira, W.; Carneiro, M.A.; Noce, C.M.; Machado. N.; Sato, K.; Taylor, P.N. 1996. Pb, Sr and Nd isotopic constraints on the Archaean evolution of gneissic granitoid complexes in the southern São Francisco Craton, Brazil. Precambrian Research, 78:151-164.

Williamson, J,H 1968. Least-squares fitting of a straight line. Canadian Journal Physics, 46:1845-1847.

Wilson, N.; Moorbath, T.; Taylor, P.N.; Barbosa, J.S.F. 1988. Archaean and early Proterozoic crustal evolution in the São Francisco Craton, Bahia, Brazil. Chemical Geology, 70:146.

Manuscrito A-991 Recebido em 15 de Janeiro de 1998 ReviSão dos autores em 15 de junho de 1998 ReviSão aceita em 16 de junho de 1998 